\title{
Human, Animal and Plant Health Benefits of Glucosinolates and Strategies for Enhanced Bioactivity: A Systematic Review
}

\author{
Sylvia Maina ${ }^{1,2,3}$, Gerald Misinzo ${ }^{2,3}$ (), Gaymary Bakari ${ }^{2}$ and Ho-Youn Kim ${ }^{1, * \mathbb{C}}$ \\ 1 Smart Farm Research Center, Korea Institute of Science and Technology (KIST), Gangneung, Gangwon 25451, \\ Korea; wairimusylvia@kist.re.kr \\ 2 College of Veterinary Medicine and Biomedical Sciences, Sokoine University of Agriculture, Morogoro 25523, \\ Tanzania; gerald.misinzo@sacids.org (G.M.); gaymary.bakari@sua.ac.tz (G.B.) \\ 3 SACIDS Africa Centre of Excellence for Infectious Diseases, Sokoine University of Agriculture, \\ Morogoro 25523, Tanzania \\ * Correspondence: hykim@kist.re.kr; Tel.: +82-33-650-3580
}

Academic Editor: Jesus Simal-Gandara

Received: 24 June 2020; Accepted: 10 August 2020; Published: 12 August 2020

\begin{abstract}
Glucosinolates (GSs) are common anionic plant secondary metabolites in the order Brassicales. Together with glucosinolate hydrolysis products (GSHPs), they have recently gained much attention due to their biological activities and mechanisms of action. We review herein the health benefits of GSs/GSHPs, approaches to improve the plant contents, their bioavailability and bioactivity. In this review, only literature published between 2010 and March 2020 was retrieved from various scientific databases. Findings indicate that these compounds (natural, pure, synthetic, and derivatives) play an important role in human/animal health (disease therapy and prevention), plant health (defense chemicals, biofumigants/biocides), and food industries (preservatives). Overall, much interest is focused on in vitro studies as anti-cancer and antimicrobial agents. GS/GSHP levels improvement in plants utilizes mostly biotic/abiotic stresses and short periods of phytohormone application. Their availability and bioactivity are directly proportional to their contents at the source, which is affected by methods of food preparation, processing, and extraction. This review concludes that, to a greater extent, there is a need to explore and improve GS-rich sources, which should be emphasized to obtain natural bioactive compounds/active ingredients that can be included among synthetic and commercial products for use in maintaining and promoting health. Furthermore, the development of advanced research on compounds pharmacokinetics, their molecular mode of action, genetics based on biosynthesis, their uses in promoting the health of living organisms is highlighted.
\end{abstract}

Keywords: glucosinolates; glucosinolate hydrolysis products; natural compounds; secondary metabolites; bioactivity; improvement; bioavailability

Academic Editor: Jesus Simal-Gandara

\section{Introduction}

Glucosinolates (GSs) are natural, sulfur-rich anionic secondary metabolites, widely distributed in plants of the order Brassicales [1], mainly in the angiosperms families like Brassicaceae. Together with glucosinolate hydrolysis products (GSHPs), they are collectively described as mustard oil glucosides [2] Only about 137 GSs have been characterized so far in plants [3]. Their core structure is composed of a $\beta$-D-glucosyl residue linked by a sulfur atom to a cis-N-hydroxyminosulfate ester, and a variable $\mathrm{R}$ group derived from a modified amino acid chain (which is the precursor used to group GSs into 
distinct classes). In plants, GS/GSHP compounds determine the distinct aroma, pungent flavors, and taste of foods [1].

GSs normally exist as intact compounds localized in vacuoles of different cell types. They are degraded to GSHPs by an endogenous glycosylated thioglucosidases enzyme known as myrosinase, which is physically separated in vacuoles of myrosin cells [4]. Myrosinase is activated upon cell disruption (e.g., during plant injury, feeding by herbivore/insects), metabolism by gut bacteria [5], usually in the presence of water. The enzyme hydrolyzes GSs thioglucoside bond producing glucose, sulfate and unstable aglycone moieties which are spontaneously rearranged to either isothiocyanates (ITCs), thiocyanates, epithionitriles, nitriles and oxazolidines, among others [1,3]. The type of GSHP compounds formed depends on the nature of the GS, reaction conditions (e.g., $\mathrm{pH}$, presence of ions) and other compounds such as ascorbic acid and epithiospecifier proteins [6].

As natural chemicals that facilitate defense responses against different types of stresses (biotic and abiotic) in plant [7], GSs/GSHPs, have other diverse functions that have caused them to quickly gain in popularity as a subject of growing scientific interest. Plants utilize the GSs-myrosinase system, the "mustard oil bomb" [8] as a self-defense system against microbes and herbivores [9], and lowering of myrosin cell activity makes plants more susceptible to predators and insects like aphids [4]. In addition, compounds released from the hydrolysis of intact GSs by myrosinase enzymes are used as biocides/biofumigants in agriculture. Pharmacological studies have also shown that GSs/GSHPs have supplemental health promoting/beneficial properties as anti-inflammatory, antimicrobial, antioxidant, cholinesterase inhibitors and as cancer preventive agents in humans, while in the food industry these compounds are used in food preservation owing to their microbial inhibitory ability [10].

The majority of the biological activities of GSs are linked to their GSHPs [11], however, intact GSs also have the capability of modulating and impacting some biological systems [12]. These activities may be enhanced by the availability of more than one compound which display synergetic mode of action between or with other compounds [13]. Certain other factors which affect the bioactivity of these compounds include the plants' GSs profiles (concentration and composition) [14] and hydrolysis enzyme actions [15]. Variations in plants' GSs profiles and enzyme activity may occur among genotypes [16], cultivars, organs [17], accessions [18], varieties [19,20], growth stage and depending on environmental or growth conditions like photoperiods [21], temperature, water, nutrient availability.

Besides the naturally available sources of GSs, recently, the prediction of new, efficient bioactive GSs/GSHPs and their derivatives have been evaluated. Among them include ITC derivatives with higher antimicrobial activity [22], chemopreventive properties [23], herbicidal activity [24], antimicrobial activity [25], anti-tumor activity [26], ITCs with moderate anti-inflammatory [27-29] and ITCs with similar anti-proliferative activity as natural ITCs [30].

Furthermore, improvement strategies of natural GSs/GSHPs compounds using elicitors or biotic and abiotic stresses; which influence concentration, biological activity, GSs-myrosinase enzyme action, have also been assessed. In response to such factors, it has been shown that the expression profiles of various transcription factors related to GSs biosynthesis differ in various genotypes, which can be used to provide genetic diversity as well as phenotypic diversity in the GSs content [31].

Through the exploration of several studies, this review aims at providing up to date information on health benefits of different types of GSs/GSHPs, and the factors that affect their natural occurrence and bioavailability, for the various beneficial health roles they possess; so as to help in investigating the therapeutic values of these compounds in future.

\section{Results}

The search identified a total of 2198 articles that were retrieved from various databases, out of which 467 were considered potentially relevant based on their titles and abstracts in the initial screening. In a second screening, 282 articles were excluded after a thorough search through the text. Finally, 185 articles met the inclusion criteria, as shown in the PRISMA flow diagram (Figure 1). 


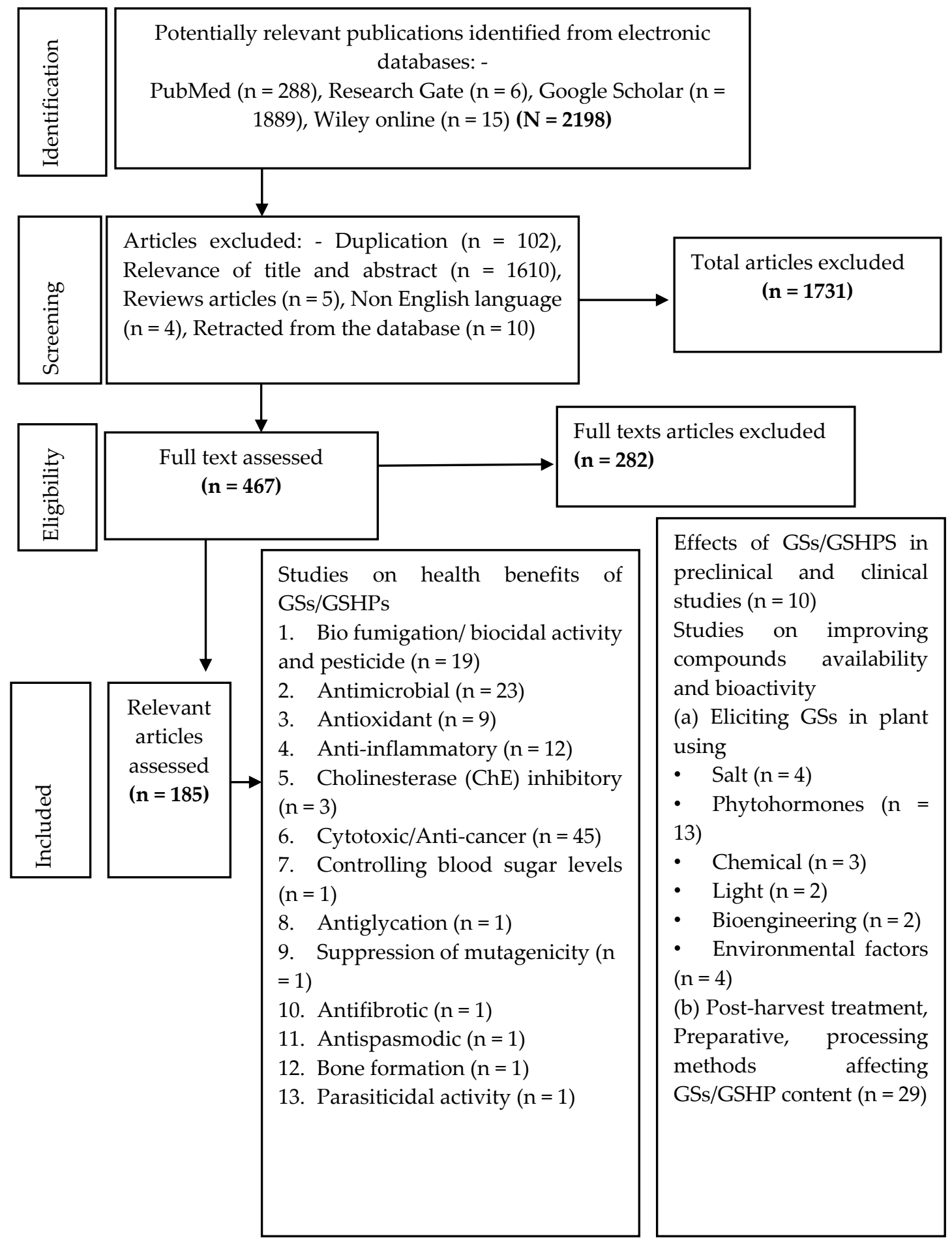

Figure 1. This figure shows the flowchart used in the article selection process.

A majority of these GSs identified from natural sources, were in plants of the Brassicaceae/Cruciferae family. Specifically, a large number belonged to the aliphatic group, followed by the aromatic/benzyl and then the indole group. The analysis of GSs/GSHPs was performed using high performance liquid chromatography (HPLC) analysis of desulfo-GSs derivatives according to the ISO-9167-1 method [32]. Among other GSs compounds mentioned, we identified that some only occur in specific families like glucocapparin in Capparaceae and glucomoringin (GMG) (4- $\alpha$-L-rhamnopyranosyloxy) benzyl GSs in Moringaceae plant species. 
Herbal preparations of GSs-rich extracts mostly focused on seeds and fully mature stages (flowers, leaves and roots) of the plants however some studies considered the utility of sprouts such as cabbage, broccoli, cauliflower, kale, brussels, radish and leaf mustard, probably due to their increased use as side dishes and salads in many countries.

The seeds, sprouts and young plant extracts, predominantly contained aliphatic groups of GSs (such as broccoli (Brassica oleracea) [14,33,34]), whose contents decreased with plant maturity whereas indole GSs contents increased. Furthermore, most of the plant, roots had higher concentration of total GSs than shoots.

Seed extracts that portrayed such benefits as chemopreventive, cytotoxic and antimicrobial include: - seed extracts of Brassica juncea L. containing 3- butenyl ITCs [35], Lobularia libyca [36], Carica papaya L. rich in benzyl GS [37], mustard seed powder [38], Sinapsis alba L. and Sinapsis nigra L. with high content of sinalbin and sinigrin, respectively [39]. GMG isolated from Moringa oleifera L. seeds possessed chemopreventive [40-42], insect larvae deterrence [43], antibacterial [44] and anti-inflammatory activity [45]. Volatiles in Lunaria annua L. seed extracts displayed cytotoxicity activity against lung cancer cells [46].

Seed meal of Brassica juncea suppressed Meloidogyne incognita nematodes individually and in specific combination with Sinapsis alba [47] while Camelina sativa L. seed meal exhibited anticancer activity [13]. Elsewehere, meadowfoam (Limnanthes alba) seed meal and extracts had photoprotective properties [48] biopesticidal activity against soil borne pathogens [49] and phytotoxic activity [50].

Volatiles in leaves extracts of Degenia velebitica [51], in aerial parts extracts of Cardaria draba L. [52] and in Aurinia leucadea [53] possessed antimicrobial activity and leaves extracts of Lepidium latifolium L. [54] had cytotoxic activity. The leaves extract from Brassica species displayed nematicidal activity [55] and chemopreventive ability [11,56,57]. The Wasabi japonica leaf extracts showed anti-neuroinflammatory effects [58], while those in horseradish (Armoracia rusticana) had antimicrobial, spasmolytic, cytotoxic activities [59,60]. Essential oils extracted from caper leaves and flower buds had anticarcinogenic activity [61]. Tumor growth inhibition and cytotocicity effects on human cancer cells were also seen in leaf extracts of Brassica carinata [62] and Eruca sativa [63] and GMG from leaves extracts of $M$. oleifera exhibited antioxidant activity [64].

Root extracts of horseradish exhibited nematicidal activity against Meloidogyne incognita [65], while those from turnip (Brassica rapa L.) had a stimulatory effect in bone formation in rats [66], while from Bunias erucago showed chemopreventive activity [67]

Sprouts extracts of Raphanus sativus L. induced apoptosis and cytotoxicity in human hepatocarcinoma cells [68] and human breast cancer cells [69]. The sprout extracts of Chinese kale (B. oleracea var. alboglabra) exhibited antioxidant activity [70]. Raphasatin in radish sprouts was also identified to be more potent as a chemopreventive compound than its corresponding GSHP [71]. Table 1 summarizes the health benefits of GSs including the herbal extracts mentioned above. 
Table 1. Various health benefits of GSs and GSHPs.

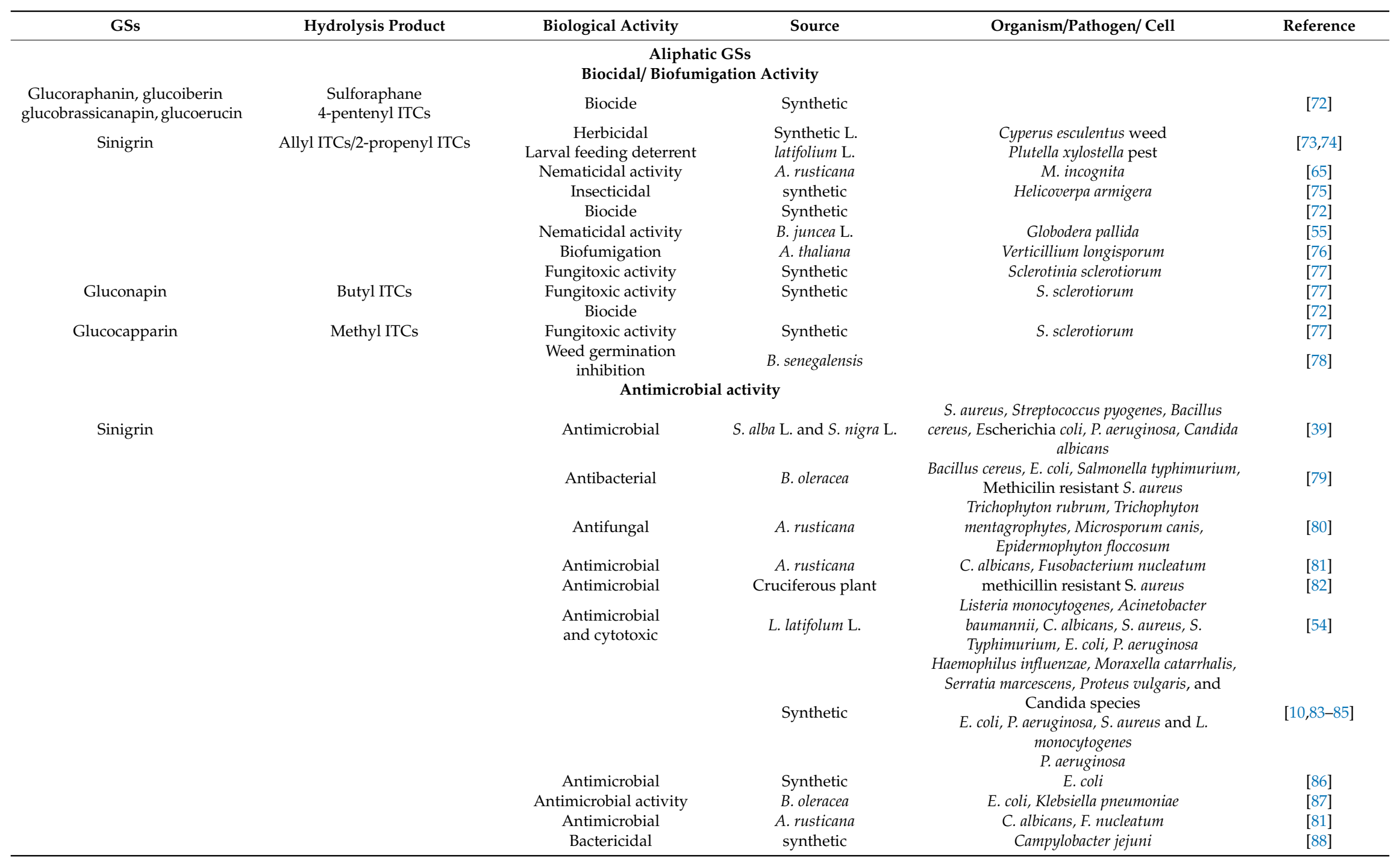


Table 1. Cont

\begin{tabular}{|c|c|c|c|c|c|}
\hline GSs & Hydrolysis Product & Biological Activity & Source & Organism/Pathogen/Cell & Reference \\
\hline Glucoraphanin & $\begin{array}{l}\text { 4-(Methylsulfanyl)butyl ITCs \& } \\
\text { 5-(methylsulfanyl)pentanenitrile }\end{array}$ & Antimicrobial & C. draba $\mathrm{L}$. & $\begin{array}{c}\text { E. coli, K. pneumonia, Enterobacter sakazakii, } P \text {. } \\
\text { aeruginosa, Cronobacter spp., S. aureus, } \\
\text { Rhizopus stolonifer }\end{array}$ & [52] \\
\hline \multirow{4}{*}{ Gluconapin } & \multirow{4}{*}{ 3-Butenyl ITCs } & Antibacterial & Synthetic & Pig aeromonas intestinal bacteria & [89] \\
\hline & & Antimicrobial & A. leucadea & $\begin{array}{c}\text { Bacillus cereus, C. albicans, Penicillium sp., } R . \\
\text { stolonifera, P. aeruginosa }\end{array}$ & {$[53]$} \\
\hline & & Antimicrobial activity & B. oleracea & E. coli, K. pneumoniae & [87] \\
\hline & & Antimicrobial & A. rusticana & C. albicans, F. nucleatum & [81] \\
\hline Glucoerucin & $\begin{array}{l}\text { 4-(Methylsulfanyl)butyl ITCs, } \\
\text { 5-(methylsulfanyl)pentanenitrile }\end{array}$ & Antimicrobial & C. draba L. & $\begin{array}{l}\text { E. coli, K. pneumonia, E. sakazakii, P. aeruginosa, } \\
\text { Cronobacter spp., S. aureus, R. stolonifer }\end{array}$ & {$[52]$} \\
\hline \multirow{3}{*}{ Glucobrassicanapin } & \multirow{7}{*}{$\begin{array}{l}\text { 6-(Methylsulfanyl) hexanenitrile } \\
\text { aliphatic ITCs and their derivatives }\end{array}$} & Antimicrobial & L. libyca & C. albicans and P. aeruoginosa & {$[36]$} \\
\hline & & Antimicrobial & Aurinia sinuate & Gram positive, negative bacteria and fungi & [90] \\
\hline & & & A. leucadea & $\begin{array}{l}\text { B. cereus, C. albicans, Penicillium sp., } R \text {. } \\
\text { stolonifera, P. aeruginosa }\end{array}$ & [53] \\
\hline Glucoalyssin & & Antimicrobial & A. leucadea & $\begin{array}{l}\text { B. cereus, C. albicans, Penicillium sp., } R . \\
\text { stolonifera, P. aeruginosa }\end{array}$ & [53] \\
\hline Glucoiberverin & & Antimicrobial activity & B. oleracea & E. coli, K. pneumoniae & [87] \\
\hline \multirow[t]{2}{*}{ Glucoberteroin } & & Antimicrobial & D. velebitica & & [51] \\
\hline & & Antimicrobial & Synthetic & Mycobacterium tuberculosis & [22] \\
\hline \multicolumn{6}{|c|}{ Antioxidant activity } \\
\hline & & & Curly kale leaves & & [92] \\
\hline Gluconapin & & Antioxidant & $\begin{array}{l}\text { B. juncea } \mathrm{L} \text {. } \\
\text { B. rapa L. }\end{array}$ & & {$[19,91]$} \\
\hline \multirow{3}{*}{$\begin{array}{l}\text { Glucoalyssin, progoitrin, } \\
\text { glucobrassicanapin, } \\
\text { Glucoiberin }\end{array}$} & & Antioxidant & B. rapa $\mathrm{L}$. & & [19] \\
\hline & & Antioxidant & Curly kale leaves & & [92] \\
\hline & \multicolumn{5}{|c|}{ Anti-inflammatory activity } \\
\hline Sinigrin & Allyl ITCs & Anti-inflammatory & $\begin{array}{l}\text { Synthetic } \\
\text { W. koreana }\end{array}$ & & $\begin{array}{l}{[93]} \\
{[58]}\end{array}$ \\
\hline \multirow[t]{4}{*}{ Glucoraphanin } & Sulforaphane & $\begin{array}{l}\text { Inflammatory } \\
\text { Prophylactic }\end{array}$ & Broccoli sprouts & & {$[94]$} \\
\hline & & Anti-inflammatory & Broccoli sprouts & & [95] \\
\hline & & & Tuscan blackkale & & [96] \\
\hline & & & B. oleracea & & [97] \\
\hline Neoglucobrassicin & & Anti-inflammatory & synthetic & & [28] \\
\hline
\end{tabular}


Table 1. Cont.

\begin{tabular}{|c|c|c|c|c|c|}
\hline GSs & Hydrolysis Product & Biological Activity & Source & Organism/Pathogen/ Cell & Reference \\
\hline \multicolumn{6}{|c|}{ Cholinesterase Inhibitory Activity } \\
\hline \multirow{2}{*}{$\begin{array}{c}\text { Gluconapin, } \\
\text { Glucoerucin } \\
\text { Glucoraphanin }\end{array}$} & \multirow{2}{*}{$\begin{array}{l}\text { But-3-enyl ITCs } \\
\text { erucin } \\
\text { sulforaphane }\end{array}$} & $\begin{array}{l}\text { Acetylcholinesterase } \\
\text { inhibitory activity }\end{array}$ & Alyssoides utriculata & & [98] \\
\hline & & Cytotoxic Activity ar & hemoprevention & & \\
\hline \multirow[t]{9}{*}{ Sinigrin } & \multirow[t]{9}{*}{ Allyl ITCs } & $\begin{array}{l}\text { Quinone reductase } \\
\text { activity }\end{array}$ & A. rusticana & Hepa1c1c7 murine hepatoma cells & [18] \\
\hline & & Cytotoxicity & Synthetic & MCL-5 cells & [99] \\
\hline & & $\begin{array}{l}\text { Anti-cancer, radical } \\
\text { scavenging ability and } \\
\text { increase ROS }\end{array}$ & B. juncea var. raya & $\begin{array}{c}\text { human breast cancer (MCF-7, } \\
\text { MDA-MB-231), prostate cancer (PC-3), lung } \\
\text { cancer (A-549), cervical cancer (HeLa) and } \\
\text { colon cancer (HCT 116) cells }\end{array}$ & [100] \\
\hline & & Anti-cancer & Mustard seed powder & $\begin{array}{l}\text { bladder cancer cell lines and orthotopic rats } \\
\text { model bladder }\end{array}$ & [38] \\
\hline & & Cytotoxic & L. latifolum $\mathrm{L}$. & Glioblastoma LN229 cells & [54] \\
\hline & & $\begin{array}{l}\text { Anti-cancer, } \\
\text { anti-melanoma }\end{array}$ & E. sativa seed oil & $\begin{array}{l}\text { HepG2 human liver carcinoma and BB16F10 } \\
\text { mice melanoma cells }\end{array}$ & [101] \\
\hline & & Anti-tumor & Collard & Human MCF-7, HeLa cells & {$[102]$} \\
\hline & & Anti-proliferative & S. alba L. and S. nigra L. & colon HCT 116 and HT-29 cells & [39] \\
\hline & & Anti-tumor & Collard & Human MCF-7 and HeLa cells & [102] \\
\hline \multirow[t]{10}{*}{ Glucoraphanin } & \multirow[t]{10}{*}{ Sulforaphane } & Chemoprevention & B. oleracea & Liver and lung cells & [103] \\
\hline & & Chemoprevention & B. oleracea & Human HepG2 hepatoma cells & [11] \\
\hline & & $\begin{array}{l}\text { Anti-cancer, } \\
\text { anti-melanoma }\end{array}$ & E. sativa seed oil & $\begin{array}{l}\text { HepG2 human liver carcinoma, BB16F10 } \\
\text { mice melanoma cells }\end{array}$ & {$[101]$} \\
\hline & & $\begin{array}{l}\text { Quinone reductase } \\
\text { activity }\end{array}$ & Chinese kales & Hepa 1c1c7 murine hepatoma cells & [106] \\
\hline & & $\begin{array}{l}\text { Quinone reductase } \\
\text { activity }\end{array}$ & E. sativa Mill & murine hepatoma Hepa1c1c7 cells & {$[107]$} \\
\hline & & Anti-metastatic & Synthetic & $\begin{array}{l}\text { MDA-MB-231(breast), Caski (cervical), A549 } \\
\text { (lung), and U2OS (osteosarcoma) cell lines }\end{array}$ & [108] \\
\hline & & Anti-cancer & Synthetic & breast cancer cell & [109] \\
\hline & & $\begin{array}{l}\text { inhibit cancer cells DNA } \\
\text { replication }\end{array}$ & Synthetic & PC-3 prostate cancer cells & {$[110]$} \\
\hline & & $\begin{array}{c}\text { upregulating } \\
\text { detoxification enzymes }\end{array}$ & Synthetic & Mouse cortical neurons & [111] \\
\hline & & Chemoprevention & Japanese Daikon & Rats liver and lung & [104] \\
\hline
\end{tabular}


Table 1. Cont.

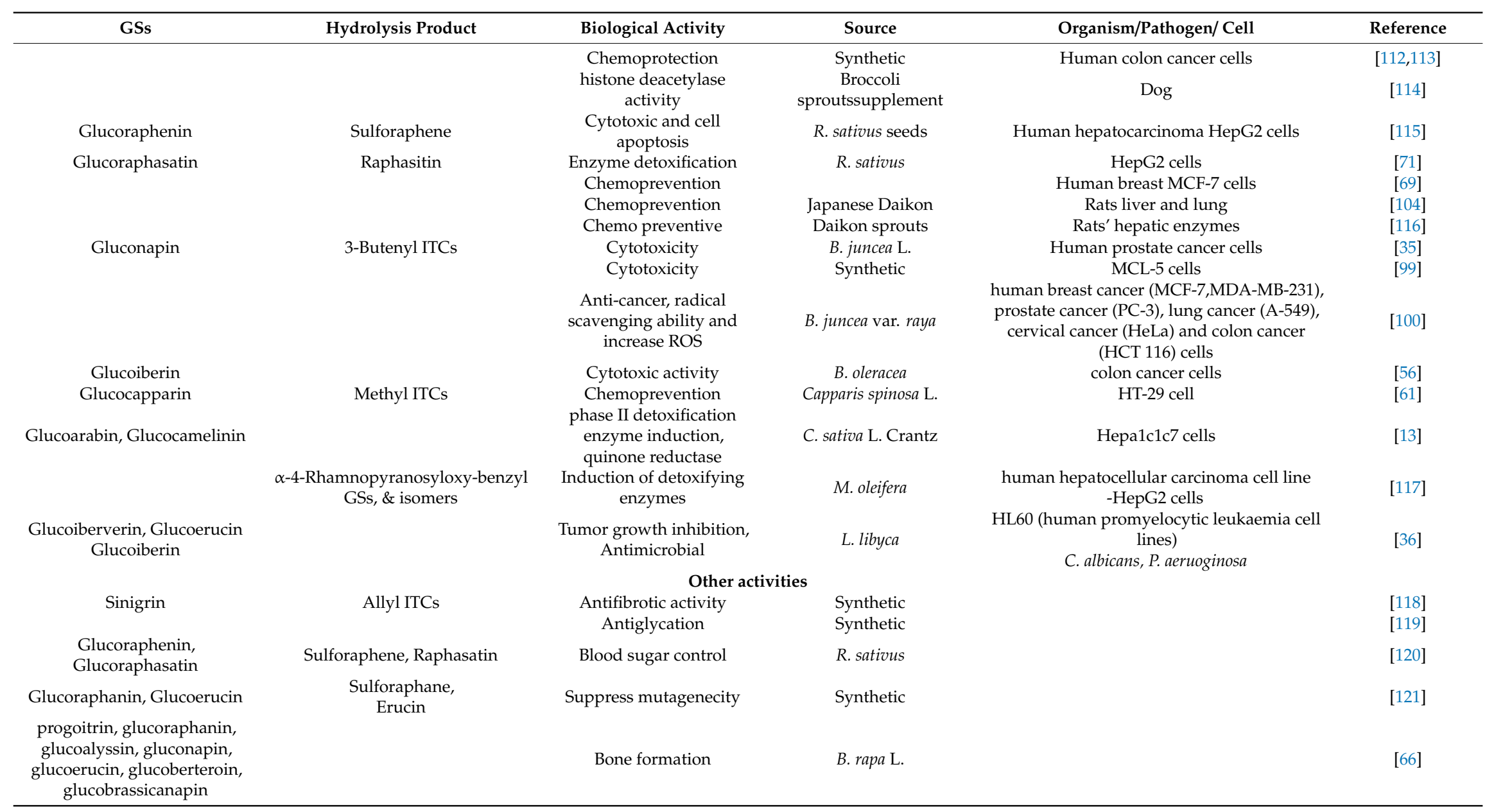


Table 1. Cont

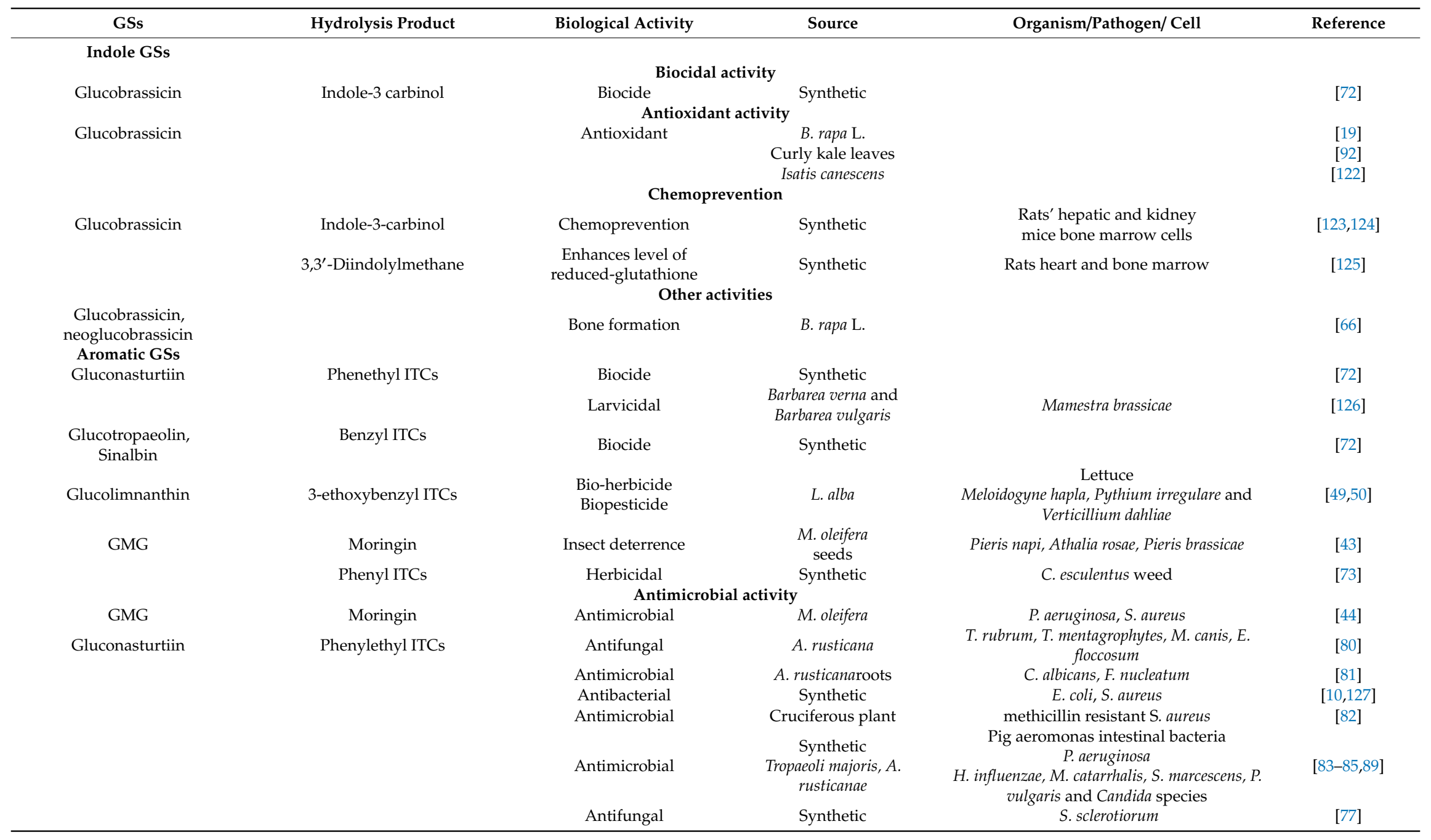


Table 1. Cont.

\begin{tabular}{|c|c|c|c|c|c|}
\hline GSs & Hydrolysis Product & Biological Activity & Source & Organism/Pathogen/Cell & Reference \\
\hline \multirow[t]{4}{*}{ Glucotropaeolin } & Benzyl ITCs & Bactericidal & Synthetic & C. jejuni & [88] \\
\hline & & Antimicrobial & Synthetic & Antimicrobial & [82] \\
\hline & & Antimicrobial & & Pig aeromonas bacteria & [89] \\
\hline & & Antifungal & Synthetic & S. sclerotiorum & [77] \\
\hline Glucobarbarin & & Larvicidal & B. verna and B. vulgaris & M. brassicae & [126] \\
\hline $\begin{array}{c}\text { p-Methoxybenzyl, } \\
\text { p-hydroxybenzyl GS }\end{array}$ & & Antifungal & Tropaeolumtuberosum & Phytophthora infestans, R. solani & [128] \\
\hline 5- Phenylpentyl ITCs & & $\begin{array}{l}\text { Antimicrobial, cytotoxic \& } \\
\text { antispasmodic }\end{array}$ & A. rusticana & $\begin{array}{c}\text { S. aureus, B. subtilis, B. cereus, S. enterica, } P \text {. } \\
\text { vulgaris, E. coli, C. albicans Aspergillus } \\
\text { brasiliensis }\end{array}$ & [59] \\
\hline \multirow[t]{3}{*}{ GMG } & & Antioxidant & M. oleifera & & [64] \\
\hline & & Anti-inflamma & ry activity & & \\
\hline & Phenyl ITCs & Anti-inflammatory & Synthetic & & [129] \\
\hline Gluconasturtiin & Phenethyl ITCs & Anti-inflammatory & Synthetic & & [130] \\
\hline GMG & Moringin & Anti-inflammatory & M. oleifera & & {$[96,131,132]$} \\
\hline \multirow{2}{*}{ 3,4-Dimethoxyphenyl } & & Anti-inflammatory & Synthetic & & [27] \\
\hline & 3-methoxyphenyl ITCS & Anti-inflammatory & synthetic & & [129] \\
\hline \multirow{3}{*}{ GMG } & & Cytotoxicity and c & moprevention & & \\
\hline & & cytotoxicity & M. oleifera & human colon adenocarcinoma grade II cells & [133] \\
\hline & & Inhibit cells proliferation & & Hep3B Liver Cancer Cells & [41] \\
\hline \multirow{4}{*}{ Gluconasturtiin } & & Chemoprevention & Synthetic & Rats' hepatic and kidney & [123] \\
\hline & & Chemoprevention & Synthetic & prostate cancer cells & [134] \\
\hline & & $\begin{array}{l}\text { Anti-cancer, } \\
\text { anti-melanoma }\end{array}$ & E. sativa seed oil & $\begin{array}{l}\text { HepG2 human liver carcinoma and BB16F10 } \\
\text { mice melanoma cell line }\end{array}$ & [101] \\
\hline & & $\begin{array}{l}\text { Inhibit multiple myeloma } \\
\text { growth }\end{array}$ & Synthetic & multiple myeloma cells & [135] \\
\hline Glucotropaeolin & Benzyl ITCs & $\begin{array}{l}\text { Anticancer activity } \\
\text { Inhibit growth }\end{array}$ & $\begin{array}{l}\text { Carica papaya } \mathrm{L} . \\
\text { Synthetic }\end{array}$ & $\begin{array}{l}\text { human lung cancer } \mathrm{H} 69 \text { cell } \\
\text { multiple myeloma cells }\end{array}$ & $\begin{array}{c}{[37]} \\
{[135]}\end{array}$ \\
\hline
\end{tabular}


Table 1. Cont.

\begin{tabular}{|c|c|c|c|c|c|}
\hline GSs & Hydrolysis Product & Biological Activity & Source & Organism/Pathogen/Cell & Reference \\
\hline & Benzyl and Phenyl ITCs & Antimetastatic & Synthetic & $\begin{array}{l}\text { MDA-MB-231 (breast), Caski (cervical), A549 } \\
\text { (lung), and U2OS (osteosarcoma) cell lines }\end{array}$ & [108] \\
\hline & $\begin{array}{l}\text { A, } \beta \text {-dialkoxyphosphoryl } \\
\text { alkyl \& aralkyl ITCs }\end{array}$ & Antiproliferative activity & Synthetic & Lung cancer cells & {$[30]$} \\
\hline & 3-Methoxybenzyl ITCs, & Photoprotective & L. alba & human skin cells & [48] \\
\hline \multirow{4}{*}{ Gluconasturtiin } & 5- Phenylpentyl ITCs & $\begin{array}{c}\text { Antimicrobial, cytotoxic \& } \\
\text { antispasmodic }\end{array}$ & A. rusticana & $\begin{array}{l}\text { S. aureus, } B \text {. subtilis, B. cereus, S. enterica, } P \text {. } \\
\text { vulgaris, E. coli, C. albicans A. brasiliensis }\end{array}$ & [59] \\
\hline & \multicolumn{3}{|c|}{ Other activities } & & \\
\hline & \multirow{2}{*}{$\begin{array}{c}\text { Phenethyl ITCs } \\
\text { Phenyl ITCs }\end{array}$} & Bone formation & B. rapa $\mathrm{L}$. & & {$[66]$} \\
\hline & & $\begin{array}{c}\text { Anti-inflammatory, } \\
\text { cholinesterase inhibitory }\end{array}$ & Synthetic & & [129] \\
\hline
\end{tabular}




\section{Benefits of Natural and Synthetic GSs and GSHP}

\subsection{Biofumigation/Biocidal Activity and Pest Management}

Natural GSs and their derivatives possess biocidal activity and show toxicity to a range of soil borne as well as plant pathogens and pests [55]. GSs rich plant sources and extracts with the ability to inhibit the growth of pathogens, offer the opportunity to explore them in controlling many plant diseases and as potential bio fumigants [72]. GSs and GSHPs volatiles, too, such as ITCs, have at low concentrations been used to control plant pathogens and/or are included as active ingredients among synthetic commercial nematicidal compounds [6]. These compounds possess bioherbicidal, larvicidal, soil fungicidal, insect feeding deterrence, nematicidal activities, and growth retardation $[49,50,65,73-77,126,128]$. Their activity and effectiveness mainly increase with exposure time and in a dose-dependent manner [73,126].

Disease suppression in soil has been done using rotations of GSs-rich green manure. Brassica juncea L. seed meal soil supplement displays greater nematotoxicity to Meloidogyne incognita pathogens and in combination with Sinapsis alba seed meal, the manure helps deter nematodes and suppresses weeds in pepper plants [47]. A similar combination displays potential in managing Verticillium wilt and soil-borne diseases [136]. B. juncea L. leaf green manure rich in 2-propenyl GSs also exhibit high nematicidal activity both In vitro and in soil microcosms [55]. Boscia senegalensis seed wastewater, rich in methyl ITCs, has allelopathic effects which cause inhibition of germination of weeds seeds [78] while non-volatile ITCs like moringin facilitates feeding deterrence of Brassicales specialists by exhibiting antifeedant activities [43].

Besides, synthetic ITCs also display potential fungicidal structure-activity relationship and they have prospective acceptability as alternatives to traditional fungicides. They include $p$-nitrophenyl which inhibits Rhizoctonia solani and Erwinia carotovora pathogens [25].

The bioprotective role of some GSs is successively promoted by the action of other compounds present in the plant. For instance, indole GSs together with the phytoalexin camalexin cause Arabidopsis thaliana resistance to the oomycete pathogen Phytophthora brassicae. While indole GSs individually inhibit host penetration and play initial defensive roles, the phytoalexin camalexin enhances the defense at later stages by adding to this initial protection [137].

\subsection{Antimicrobial Activity}

Microbial drug resistance, pathogen resistance, food spoilage, clinical and oral microbial pathogens are becoming a global problem. Thus, there have been increasing efforts to evaluate natural products as a source of compounds against these agents. GSs/GSHPs are among the most important natural products whose antimicrobial mode of action has been characterized [10,36,82-84].

The antimicrobial activity of plant extracts possessing therapeutic potential relies on the presence of volatiles, among which GSs and GSHP compounds have been well identified. Studies focusing on these compounds and their antimicrobial activities show that active compounds affect pathogens' membrane integrity [127], intracellular potassium release [10], inhibit growth in pathogens [22,36,39,51-54,79,80,83,87,89,90], kill pathogens $[81,82,88]$ and change physiochemical surface properties and charges. Inhibitory effects of GSs and GSHPs can be non-selective [59] or may vary between different pathogens, as illustrated by allyl and phenylpentyl ITCs in A. rusticana which has higher antifungal activity than antibacterial activity [80].

Natural and synthetic volatile ITCS compounds have also been shown to inhibit the growth of drug-susceptible and multidrug-resistant (MDR) pathogens at concentrations comparable to the commonly used antimicrobial drugs [22]. Furthermore, they show even higher activity against MDR strains compared to susceptible strains, as in the case of Mycobacterium tuberculosis [22].

The effectivity of GSHPs as antimicrobial compounds can be increased by combining them with less efficient antibiotics [84,127], (which results in synergism) and/or having a mixture of several ITCs that display a broad-spectrum antimicrobial activity even to MDR pathogens [83,85]. Bioactivation of GSs 
with myrosinase enzyme also maximizes their effectiveness and antimicrobial activity, as demonstrated by enzyme bioactivated GMG activity against Pseudomonas aeruginosa and Staphylococcus aureus [44]. Food-borne bacteria synthesize myrosinase enzyme, which also influences the conversion of GSs to their GSHPs and increases their potency as antimicrobials [86].

\subsection{Antioxidant Activity}

Reactive oxygen species and free radicals produced by several metabolic processes have very high potential to harm cells through oxidation. Their continued presence speeds up aging resulting in age-related illnesses [138]. Several antioxidants studies show that GSs/GSHPs can scavenge and eliminate the damaging effects of the reactive oxygen species directly or indirectly [64].

The various GSs abundant plants showing potential antioxidant activity include Chinese cabbage (B. rapa L.) varieties [19], B. juncea L. (kimchi) [139], Isatis canescens flower buds [122], leaves of Eruca sativa Mill [140], Brassica olerecea L. sprouts [141], B. juncea L. leaves and seeds extracts [91], and curly kale leaves juice [92]. Plant extracts with antioxidant activity can be optimized by choosing appropriate conditions for their processing and storage, as demonstrated in fermented kimchi [139]. Elsewhere, synthetically obtained phenyl ITCs and their derivatives also display good antioxidant activity [129].

\subsection{Anti-Inflammatory Activity}

GSs and GSHPs have shown great potential as anti-inflammatory agents through their ability to suppress inflammatory mediators independently or with other substances [131]. Phenethyl ITCs down-regulate the nuclear factor $\mathrm{\kappa B}$ pathway, subsequently inhibiting transcription of genes involved in inflammatory effects, on a mouse ear topically applied with an inflammation-inducing substance [130]. In combination with 3-methoxyphenyl ITCs, phenyl ITCs cause approximately 99\% inhibition on the human cyclooxygenase-2 enzyme [129].

The anti-inflammatory activity of GSs/GSHPs is presented in various ways for different cells. Plant extracts of Wasabi koreana, containing allyl ITCs, protect neuronal cells from activated microglia induced toxicity by inhibiting activation of nuclear factors [58] while sulforaphane isolated from broccoli sprouts improve cognitive function among schizophrenic patients [95]. Myrosinase- activated GMG [45] and glucoraphanin [97] act as potent anti-inflammatory agents by inducing inflammatory pathways.

Anti-inflammatory activity may be established in a concentration-dependent manner, as shown by sinigrin which suppress the production of inflammatory mediators in activated macrophages by inhibiting lipopolysaccharide-induced nitric oxide pro-inflammatory mediators [93]. To achieve maximal activity it is worth activating compounds as in the case of bioactive glucoraphanin that preserves tight junctions' integrity preventing dysfunctional blood-brain barriers in autoimmune encephalomyelitis, causing multiple sclerosis [96]. Furthermore, synthetically produced GSHPs are worth evaluating for their activity like indole GSs [28], and aromatic GSs [27] which have an inhibitory effect in the secretion of tumor necrosis factor- $\alpha$ in human monocytic leukaemia T peripheral helper- 1 cells stimulated with lipopolysaccharides.

\subsection{Cholinesterase (ChE) Inhibitory Activities}

GSHPs, mainly volatile ITCs, demonstrate potential in anti-hepatotoxic activity. They include gluconapin, glucoerucin, and glucoraphanin that display above 53\% acetylcholinesterase (AChE) inhibitory activity in a dose-dependent manner [98]. Hydrodistillate extract from Bunias erucago flowers, rich in glucosinalbin, shows a best AChE inhibition of $40.9 \%$ while roots extract displays a butyrylcholinesterase inhibition activity of 54.3\% [67].

In addition to natural GSs, synthetic GSHPs and their derivatives also show good cholinesterase inhibitory activity. This has been illustrated in phenyl ITCs and its derivatives that display the most promising inhibitory activity with potential applications in treating Alzheimer's disease [129]. 


\subsection{Cytotoxic and Anti-Cancer Activity}

The mechanisms contributing to the anti-tumor and/or chemopreventive properties of GSs/ GSHPs are varied, as shown in various studies included in this review. Compounds may act by inducing/modulating systems of carcinogen detoxifying/metabolizing enzymes [103,117] which include increased detoxification, they may also act by upregulating phase II enzymes such as glutathione-S-transferase $[104,123,125]$ and quinone reductase $[11,13,18,71,106,107]$. These mechanisms may be organ specific [123], may depend on the compound enantiomer involved [103], on the amounts of compounds [142], and on the availability of various compound which produce synergistic action [13].

GSHPs-ITCs may inhibit enzyme activity, as evidenced in 2-propenyl and 3-butenyl ITC that inhibit cytochrome P450 1A enzyme activity [99]. The compounds may also display selective anticancer activity that results in the inhibition of deoxyribonucleic acid replication in cancer cells as shown by sulforaphane and phenethyl ITCs, causing more double strand breaks in prostate cancer cells [110].

Furthermore, GS/GSHP compounds exhibit radical scavenging ability and cytotoxic effects in various cancer cells. Compounds like butenyl thiocyanates, allyl, phenethyl ITCs [100], and GMG GSs [133] reveal such effects. The compounds' effectivity lies in their ability to inhibit cell proliferation, [37,39,61] arrest the cell cycle [38], causing morphological changes, cytotoxicity, and cell apoptosis [35,36,40,41,54,56,59,69,101,113,115,119]. These activities may be dose dependent [37] and may also be defined by the chemical nature of the compound [143]. Sometimes, the dynamism of these activities occurs through synergic effects [105] of various compounds present in an extract and the particular extract's vigor is affected by the method of preparation [102].

Some GSs/GSHPs display their potential by possibly inhibiting compounds or activities related to cancers. Among them include, phenyl ITCs that inhibit transcriptional activity regulated by androgen receptor modulating growth of prostate cancer cells through down-regulation of an androgen receptor-regulated gene [134]. ITCs may influence changes and activity of compounds that are normally overexpressed during cancer such as histone deacetylase [112,114] or compounds which may cause intoxication such as doxorubicin [124].

GSs/GSHPs exhibit the ability to suppress healthy cell invasion and abolish the growth of tumors by affecting pathways that adjust carcinogen metabolizing compounds. These include sulforaphane ITCs, which down regulates the expression of matrix metalloproteins [108]. Such ITCs may activate the antioxidant response element electrophile response element/antioxidant responsive element, modulating estrogen signaling in different tissues that leads to induction of the inhibitory effects of estrogen in breast cancer cells [109], while in cortical neurons, they activate the extracellular signal regulated kinase pathway, transcriptional factors, and upregulate detoxification enzymes [111]. Benzyl and phenethyl ITCs show significant inhibition of the proteasome activity and also suppress the growth of multiple myeloma cells [135].

The photoprotective properties of 3-methoxybenzyl ITCs and 3-methoxyphenyl acetonitrile, in Limnanthes alba, display their anti-photocarcinogenic and anti-photoaging properties. These ITCs induce human skin cell proliferation activity against ultraviolet $B$ rays and prevent hyperplasia induced by these rays in reconstructed skin epidermal tissue [48].

\subsection{Other Activities}

Sulforaphene and raphasatin ITCs reduce the risks of sugar-related diseases. In addition, these compounds cause spargel expression, which modulates energy metabolism, inhibiting $\alpha$-amylase, and $\alpha$-glucosidase in vitro [120]. Elsewhere, sulforaphane and phenethyl ITCs suppress urinary mutagenicity activity as illustrated on rats treated with oral doses of heterocyclic amine 2-amino-3-methylimidazo[4,5-f]quinoline, a food carcinogen. Long term intake of the ITCs decreases urinary mutagenic activity, implying enhanced/modulation of the metabolism of the quinoline [121].

Sinigrin, a common GS in most cruciferous vegetables, exhibits the great potential of inhibiting non-enzymatic aglycation [119], while its GSHP allyl ITCs has hepatoprotective roles (reduction of hepatic fibrosis). In rats exposed to carbon tetrachloride $\left(\mathrm{CCl}_{4}\right)$, the ITCs reduce alanine 
aminotransferase and aspartate aminotransferase activity, activate macrophages and regulate Kupffer cells [118].

The potential stimulatory effect of GSs in bone formation, and as natural sources of promising neutraceutical agents has been shown in B. rapa L. roots GSs, that show stimulatory effects on human osteoblast-like MG-63 cell differentiation. Administration to young rats increases serum osteocalcin as well as some bone microstructural parameters [66]. In addition, 5-phenylpentyl ITCs isolated from A. rusticana exert significant spasmolytic activity on rats' distal colon [59].

Functional foods based on GSs display parasiticidal potential against Lepeophtheirus salmonis lice, ectoparasites that infect Atlantic salmon. In an in vivo study that involved various feeding trials on fish, beneficial effects on expression of genes functioning in detoxification and regulation of iron metabolism in several tissues are shown. Such properties affect the availability of heme to lice, deterring them from infesting the fish [144].

\subsection{Effects of GSs/GSHPs Used in Preclinical and Clinical Studies}

Clinical and preclinical studies evaluating GSs/GSHPs components and diets provide the basis for further explaining the mechanism of action of these components. Broccoli sprouts, rich in sulforaphane administered in a pilot study on melanoma patients display chemoprevention ability [145] and shows favorable effects in reduction of serum insulin while at the same time enhances insulin resistance in type 2 diabetes patients, therefore improving their glycaemic control and decreasing risk factors of cardiovascular diseases [146]. Broccoli soup consumption also reduces the risk of prostate cancer progression [147] and daily administration of free sulforaphane shows promising evidence in managing biochemical recurrence after radical prostatectomy in patients with prostate cancer [148]. Similarly, in asthmatics, sulforaphane enhanced bronchoconstrictor effect, improving major defects and even mild asthma [149] and in schizophrenic patients, sulforaphane from broccoli sprouts helped in improving their cognitive function [95].

Clinical studies, however, require a good design that follows a standardized protocol which includes selecting a representative sample size and various doses [148] of the phytochemicals to minimize bias and allow generalization. Likewise, masking and the duration of treatments [146,150]/interventions/exposure/supplementation [151] should be well considered to confirm specific effects of the components. Variabilities in concentrations of GSs/GSHPs consumed need to be minimized in the diet within these studies. Furthermore, research on the mechanism of action, probably in the biomarker-based approach of GSs/GSHPs is highly recommended to understand various relationships between exposure and risks of the phytochemicals as reported in some studies $[152,153]$. Table 2 summarizes some preclinical and clinical studies evaluating the health benefits of GSs and GSHPs.

\subsection{Improving Plant GSs, GSHPs Content, Their Bioavailability, and Bioactivity}

There are several factors that affect GSs contents/composition as well as their biological activities. These include (a) post-harvest treatment of GSs rich plant [154-156], (b) preparative activities like boiling and nature of vegetables (like those with thick waxy tissues have minimal leaching of GSs into the boiling medium) [157]; (c) extraction solvent polarity [46,158]; and (d) extraction technique [39,60,132,159,160]. 
Table 2. Summary of some preclinical and clinical studies evaluating the health benefits of GSs and GSHPs.

\begin{tabular}{|c|c|c|c|c|c|c|c|}
\hline Patient's Condition & Participants Enrolled & Groups and Doses & Duration & Analysed & Clinical Outcomes & Results & Reference \\
\hline Melanoma & 17 & $\begin{array}{c}3 \text { groups, } 3 \text { oral doses }(50,100 \\
200 \mu \text { moles) of broccoli sprouts } \\
\text { extract containing sulforaphane } \\
\text { (SFN) }\end{array}$ & 28 days & 17 & $\begin{array}{l}\text { sulforaphane levels in } \\
\text { plasma and skin, plasma } \\
\text { cytokines, Safety, tissue } \\
\text { proteomics }\end{array}$ & $\begin{array}{c}\text { Detectable SFN in plasma, } \\
\text { cytokines decreased, } \\
\text { extracts tolerated up to } \\
200 \mu \text { mol, increased tumor } \\
\text { suppressors }\end{array}$ & [145] \\
\hline Type 2 diabetes patients & 81 & $\begin{array}{c}3 \text { groups (2 received } 10 \mathrm{~g} / \text { day }(\mathrm{d}) \\
\text { broccoli sprout powder (BSP) and } \\
5 \mathrm{~g} / \mathrm{d} \text { BSP and the third received the } \\
\text { placebo }\end{array}$ & 4 weeks & 72 & $\begin{array}{l}\text { Insulin concentration, } \\
\text { fasting serum glucose, } \\
\text { glucose: insulin ratio, } \\
\text { homeostasis model of } \\
\text { insulin resistance index }\end{array}$ & $\begin{array}{l}10 \mathrm{~g} / \mathrm{d} \text { BSP significantly } \\
\text { decreased serum insulin } \\
\text { concentration, and } \\
\text { improved insulin resistance } \\
\text { in patients }\end{array}$ & [146] \\
\hline $\begin{array}{l}\text { Low and intermediate } \\
\text { risk prostate cancer } \\
\text { patients }\end{array}$ & 61 & $\begin{array}{l}3 \text { groups received each } 300 \mathrm{~mL} \text { of } \\
\text { different broccoli soup (rich in } \\
\text { glucoraphanin) weekly }\end{array}$ & 12 months & 48 & $\begin{array}{l}\text { Tissues } \\
\text { examination/prostate } \\
\text { pathology and RNA } \\
\text { sequencing analysis for } \\
\text { gene expression }\end{array}$ & $\begin{array}{c}\text { Reduction of prostate } \\
\text { cancer progression. Soups } \\
\text { with high glucoraphanin } \\
\text { content caused suppression } \\
\text { in expression. }\end{array}$ & [147] \\
\hline $\begin{array}{l}\text { Patients with recurrent } \\
\text { prostate cancer }\end{array}$ & 20 & $\begin{array}{l}200 \mu \text { moles/day of sulforaphane rich } \\
\text { extract broccoli sprouts }\end{array}$ & 20 weeks & 16 & $\begin{array}{l}\text { Safety of doses, Prostate } \\
\text { specific antigen (PSA)\% } \\
\text { levels }\end{array}$ & $\begin{array}{c}\text { Treatment was safe, } \\
\text { exhibited anti-tumor } \\
\text { potential, majority of } \\
\text { patients didn't get reduced } \\
\text { PSA levels }\end{array}$ & [148] \\
\hline Asthmatic patients & 51 & $\begin{array}{c}100 \mu \text { moles/day of sulforaphane rich } \\
\text { broccoli sprouts extract }\end{array}$ & 14 days & 45 & $\begin{array}{l}\text { Pulmonary functions, } \\
\text { NAD }(\mathrm{P}) \mathrm{H} \text { quinone } \\
\text { dehydrogenase-1 gene } \\
\text { expression, safety }\end{array}$ & $\begin{array}{c}\text { Enhanced } \\
\text { bronchoconstrictor effects, } \\
\text { increased gene expression } \\
\text { also enhanced } \\
\text { broncho-protection }\end{array}$ & [149] \\
\hline $\begin{array}{l}\text { Women with abnormal } \\
\text { mammograms }\end{array}$ & 54 & $\begin{array}{c}2 \text { groups; group1: (2 pills, } \\
3 \text { times/day of } 30 \text { mg glucoraphanin), } \\
\text { group } 2 \text { placebo }\end{array}$ & 2 to 8 weeks & 48 & $\begin{array}{l}\text { Sulforaphane in blood and } \\
\text { urine, tissue biomarkers }\end{array}$ & $\begin{array}{l}\text { Safe but not efficient to } \\
\text { produce the changes in } \\
\text { breast tissue tumor } \\
\text { biomarkers }\end{array}$ & [151] \\
\hline Schizophrenia & 10 & $\begin{array}{c}3 \text { tablets/30 mg of Sulforaphane per } \\
\text { day }\end{array}$ & 8 weeks & 7 & $\begin{array}{l}\text { Evaluation of Symptoms } \\
\text { using positive and } \\
\text { negative syndrome scale } \\
\text { and cognitive function }\end{array}$ & $\begin{array}{l}\text { Sulforaphane potentially } \\
\text { improved cognitive } \\
\text { function }\end{array}$ & [95] \\
\hline
\end{tabular}


Salt stress, in a concentration-dependent manner, is a potential inducer of producing these health-promoting compounds. Sodium chloride treatment increases glucoraphasatin on radish sprouts [161], and sulforaphane in broccoli sprouts [162]. Salt stress in combination with elevated carbon dioxide increasing sulphur cellular partitioning and metabolism which affects the GSs-myrosinase system [163]. Similarly, sulphur salts supplementation during the cultivation of vegetables increases GSs content and their biological activities [68].

Exogenous application of phytohormones triggers/manipulates GSs, GSHPs, and their related gene expression profiles. Among the phytohormones used include methyl jasmonic acid (MeJA) [164], gibberellic acids (GA3) in combination with glucose [70] and jasmonic acid (JA) [165]. A $250 \mu \mathrm{M}$ MeJA spray treatment on Brassica napus var. pabularia seedlings [166] and B. oleracea var. green magic before harvesting [164] induces GSs. As GSs content increase during MeJA treatment, there is a simultaneous enhancement of biological activity [57,167-170]. The GSs content changes observed in plant may be cultivar specific [171]. A combination of $5 \mu \mathrm{M} \mathrm{GA}_{3}$ and $3 \%$ glucose in Chinese kale sprouts increases GSs content and enhances their biological activities [70]. Also, JA treatments enhance the accumulation of aliphatic GSs, increase myrosinase activity and GSHP production [165].

Overexpression of genes involved in the breakdown of GSs defends plant against pathogens. In A. thaliana, overexpression of myrosinase gene TGG1, affects the metabolism of GSs compounds enhancing plant stomatal defense against Pseudomoas syringae bacteria [172].

The treatment of plants with trace/essential elements affects the GSs-myrosinase system. Selenium treatment for instance, increases sulforaphane in broccoli cultivars sprouts, enhancing their myrosinase activity [34] while in $R$. sativus an increment in glucoraphanin is observed [173]. In A. thaliana and B. oleracea Var. italica, ammonium nutrition stimulates the accumulation of GSs and induces myrosinase activity as well [174]. Managing plants using chemicals and light may increase GSs content, for instance 6-benzylaminopurine [175] alone and in combination with 1-methyl-cyclopropene [176] increases GSs in broccoli and green light emitting diode lights increase broccoli's florets' total GSs content and sulforaphane [177]. Elsewhere, GSs in plants may accumulate through natural occurrences, in response various stresses like yearly seasonal variations that cause increased temperatures, water stress [168], larval/herbivore infestation [166,178,179], ozone fumigation [180], and biotechnological transformations [172,181].

Dietary intake of GSs rich products is positively correlated to their health benefits and biological activity. Their bioavailability can be enhanced by increasing the hydrolysis enzyme activity and/or treating extracts in mild heat [182]. Continuous consumption of GSs rich foods is exogenously treated with myrosinase [183-186] or intake of diverse GSs rich foods which increase the activity of the GSs degradation enzyme in the gut results into the bioavailability of GSs/GSHPs [187]. The content of these compounds in prepared and processed food is essential and therefore, post-harvest processing techniques, food processing, and treatment methods that affect the contents of GSs and the biological activities should be carefully chosen. Pasteurization [92], high pressure [188,189] treatments and freezing [190,191], thermal boiling [133,157,192], steaming [193], microwaving [46,194,195], storage time [139], storage temperatures [196] affect to GSs contents. On the other hand, blanching is considered to prevent loss of phytochemicals [102] in vegetables. Tables 3 and 4 summarize the factors and treatments which affect the availability and activity of GSs/GSHPs in plant or diet and the hydrolysis activity of myrosinase enzyme. Several substances that have been used in the elicitation of GSs/GSHPs have shown not only to induce physiological changes but also stimulate various biological activities, as illustrated. 
Table 3. Improving GSs/ GSHPs and bioactivity in plant.

\begin{tabular}{|c|c|c|c|c|}
\hline Treatment/Factor & Plant & GSs & Biological Activity & Reference \\
\hline Sodium chloride & $\begin{array}{l}\text { Radish sprouts } \\
\text { Broccoli sprouts }\end{array}$ & $\begin{array}{c}\text { Total GSs, Glucoraphasatin } \\
\text { Sulforaphane }\end{array}$ & $\begin{array}{l}\text { Antioxidant } \\
\text { activity }\end{array}$ & {$[161,162]$} \\
\hline $\begin{array}{l}\text { Salinity and carbon } \\
\text { dioxide }\end{array}$ & B oleracea & $\begin{array}{l}\text { Indolic GSs, aliphatic GSs } \\
\text { respectively }\end{array}$ & - & [163] \\
\hline \multirow[t]{6}{*}{$\begin{array}{c}\text { Sulphur salt } \\
\text { supplementation }\end{array}$} & $\begin{array}{c}\text { B. oleracea Var. } \\
\text { capitata, R. sativus }\end{array}$ & $\begin{array}{l}\text { Total GSs, progoitrin, } \\
\text { glucoerucin, glucobrassicin, } \\
\text { glucohirsutin and 4- } \\
\text { methoxybrassicin }\end{array}$ & $\begin{array}{l}\text { Antioxidant, anti- } \\
\text { proliferative }\end{array}$ & [68] \\
\hline & B. napus, B.oleracea & $\begin{array}{c}\text { gluconasturtiin, } \\
\text { glucobrassicin, } \\
\text { neoglucobrassicin, } \\
\text { glucoraphanin } \\
\text { glucobrassicin, }\end{array}$ & Quinone reductase & [164] \\
\hline & Broccoli florets & $\begin{array}{l}\text { neoglucobrassicin, } \\
\text { gluconasturtiin }\end{array}$ & Quinone reductase & [169] \\
\hline & $\begin{array}{l}\text { B. rapa ssp. } \\
\text { Chinensis }\end{array}$ & $\begin{array}{l}\text { 1-methoxy-3-indolylmethyl } \\
\text { GSs }\end{array}$ & \multirow{3}{*}{$\begin{array}{c}\text { Mutagenecity } \\
- \\
- \\
-\end{array}$} & \multirow{3}{*}[57,166,170,171]{} \\
\hline & B. rapa $\mathrm{L}$. & $\begin{array}{c}\text { Indole GSs } \\
\text { Total }\end{array}$ & & \\
\hline & $\begin{array}{l}\text { B. napus var. } \\
\text { pabularia } \\
\text { B. oleracea }\end{array}$ & $\begin{array}{l}\text { glucobrassicin, } \\
\text { neoglucobrassicin, } \\
\text { gluconasturtiin }\end{array}$ & & \\
\hline $\begin{array}{c}\text { MeJA, high } \\
\text { temperature, water } \\
\text { stress }\end{array}$ & Broccoli cultivars & Total GSs & Quinone reductase & [168] \\
\hline GA3 with glucose & B. oleracea & Indolic GSs & Antioxidant & [70] \\
\hline JA & $\begin{array}{l}\text { B. oleracea var. } \\
\text { italica }\end{array}$ & Glucoraphanin & Not evaluated & [165] \\
\hline Selenium & $\begin{array}{l}\text { Broccoli sprouts } \\
\text { R. sativus }\end{array}$ & $\begin{array}{l}\text { Sulforaphane } \\
\text { Glucoraphanin }\end{array}$ & Not evaluated & $\begin{array}{c}{[34]} \\
{[173]}\end{array}$ \\
\hline $\begin{array}{l}\text { Nitrogen nutrition } \\
\text { (Ammonium) }\end{array}$ & $\begin{array}{l}\text { A. thaliana and } B . \\
\text { oleracea Var. italica }\end{array}$ & GSs & Not evaluated & [174] \\
\hline Ozone & $\begin{array}{l}\text { Brassica oleracea var. } \\
\text { capitata f. alba }\end{array}$ & Sinigrin & Antioxidant & [180] \\
\hline 6-benzylaminopurine & B. oleracea & Total GSs and sulforaphane & \multirow[t]{4}{*}{ Antioxidant } & {$[175,176]$} \\
\hline Green LED light & B. oleracea & Total GSs & & [177] \\
\hline Larval infestation & B. napus var. & $\begin{array}{l}\text { Indole GSs } \\
\text { Ind }\end{array}$ & & \multirow[b]{2}{*}[166,178,179]{} \\
\hline $\begin{array}{l}\text { Delia radicum root } \\
\text { herbivory } \\
\text { D. radicum and } \\
\text { Delia floralis }\end{array}$ & $\begin{array}{l}\text { pabularia } \\
\text { B. rapa } \mathrm{L} \text {. } \\
\text { B. rapa varieties }\end{array}$ & $\begin{array}{c}\text { Benzyl and indole GSs in roots } \\
\text { Aliphatic, indole and benzyl } \\
\text { GSs in roots of high GSs } \\
\text { varieties }\end{array}$ & & \\
\hline BoTGG1 Gene & A. thaliana & GSs & $\begin{array}{l}\text { Bacterial pathogens } \\
\text { attack }\end{array}$ & [172] \\
\hline
\end{tabular}

Table 4. Improving GSs/ GSHPs bioavailability and bioactivity.

\begin{tabular}{|c|c|c|c|c|}
\hline Treatment & Source & Effects & Biological Activity & \\
\hline Mild heat treatment & B. rapa $\mathrm{L}$. & Myrosinase enzyme activity & & [182] \\
\hline $\begin{array}{l}\text { Continuous } \\
\text { consumption }\end{array}$ & Broccoli & $\begin{array}{l}\text { Total ITCs in colon and } \\
\text { caecum levels of male mice }\end{array}$ & $\begin{array}{c}\text { Quinone } \\
\text { oxidoreductase }\end{array}$ & [187] \\
\hline $\begin{array}{c}\text { Exogenous myrosinase } \\
\text { treatment }\end{array}$ & $\begin{array}{l}\text { Broccoli sprouts } \\
\text { Cooked broccoli } \\
\text { Mustard powder }\end{array}$ & $\begin{array}{l}\text { Sulforaphane in diet } \\
\text { Sulforaphane in cooked } \\
\text { vegetables } \\
\text { Enzyme activity }\end{array}$ & $\begin{array}{l}\text { Sulforaphane } \\
\text { Plasma levels } \\
\text { Urinary } \\
\text { sulforaphane levels } \\
\text { Antimicrobial }\end{array}$ & {$[183,184,186]$} \\
\hline Powdered mustard seeds & $\begin{array}{l}\text { B. oleracea var. } \\
\text { italica }\end{array}$ & $\begin{array}{l}\text { Sulforaphane in processed } \\
\text { vegetables }\end{array}$ & - & [185] \\
\hline
\end{tabular}




\section{Materials and Methods}

\section{Search Strategy and Selection Criteria}

Peer-reviewed articles were searched using keywords in various scientific databases, including PubMed, ResearchGate.net, Wiley Online Library, and Google Scholar, between March 2010 and March 2020. The search terms used to obtain articles for this review were "glucosinolate" OR "glucosinolate extract" OR "plant glucosinolate" OR "glucosinolate isolate" OR "pure glucosinolate" OR "synthetic glucosinolate" OR "glucosinolate hydrolysis product" OR "Glucosinolate degradation product" OR "mustard oil glucoside" OR "myrosinase end product" OR "isothiocyanate" OR "benzyl glucosinolate" OR "indole glucosinolate " combined with "profile" OR "availability" OR "variability" AND "activity" OR "Bioactivity" OR "health benefits" OR "specific biological activities" AND "improvement" OR "elicitor". Data extraction included the specific glucosinolate/ glucosinolate hydrolysis products, their sources, biological activities, mode of action, availability, strategies used to increase their content availability and activity. Articles published in a non-English language, before and/or after the set period, retracted from the databases, having self-reported outcomes, and reviews and editorials, were excluded. The review focused on the peer-reviewed original studies with a particular outcome of interest, depending on the study objective.

\section{Conclusions}

GSs/GSHPs offer a wide variety of health benefits, including disease prophylactic and therapeutic effects. This review shows the usefulness of these compounds in preventing and reducing disease progression in humans and animals, their biocidal, biofumigation capabilities in plants, and their antimicrobial use in the food industry as food preservatives.

Although their composition and concentration vary in various crop species, organs, cultivars, and at different stages of development, sometimes in response to both abiotic and biotic factors, strategies to improve specific compounds have been successful, leading to improved crop varieties with both nutritional and pharmacological benefits. Biological activity assays on GSs-rich extracts exhibit a positive correlation between concentrations of GSs/GSHPs-related benefits in organisms. Taking this into consideration, the bioavailability of these compounds should be well maintained in their sources through choosing and having handling, preparative techniques, extraction methods that maintain them.

This review also reveals the necessity to maintain GSs content as bioactive compounds, to explore and improve GSs rich plant as a source of these natural compounds, which have potential as active ingredients among synthetic and commercial products to maintain and promote health. Considering that most research evaluating these natural compounds mainly focuses on the plant of Brassicaceae family, there is furthermore a need to probe the compounds even more in vivo studies, to understand their primary mechanism of actions and their molecular targets should also be emphasized.

Author Contributions: Literature research and writing of this manuscript was done by S.M., H.-Y.K. provided the subject matter expertise and guidance on the manuscript. G.M. and G.B. revised and finalized the manuscript. All authors have read and agreed to the published version of the manuscript.

Funding: This research received funding from the Regional Scholarship and Innovation Fund of the Partnership for Skills in Applied Sciences, Engineering and Technology (RSIF-PASET) in collaboration with the Government of the Republic of Korea and supported by the intramural grant (2Z06110) from the Korea Institute of Science and Technology (KIST), Republic of Korea.

Conflicts of Interest: The author declares no conflict of interest in this review. 


\section{References}

1. Clarke, D.B. Glucosinolates, structures and analysis in food. Anal. Methods 2010, 2, 310-325. [CrossRef]

2. Heldt, H.-W.; Piechulla, B. Secondary metabolites fulfill specific ecological functions in plants. Plant Biochem. 2011, 399-408. [CrossRef]

3. Blažević, I.; Montaut, S.; Burčul, F.; Olsen, C.E.; Burow, M.; Rollin, P.; Agerbirk, N. Glucosinolate structural diversity, identification, chemical synthesis and metabolism in plants. Phytochemistry 2020, 169, 112100. [CrossRef] [PubMed]

4. Borgen, B.H.; Ahuja, I.; Thangstad, O.P.; Honne, B.I.; Rohloff, J.; Rossiter, J.T.; Bones, A.M. “Myrosin cells" are not a prerequisite for aphid feeding on oilseed rape (Brassica napus) but affect host plant preferences. Plant Biol. 2012, 14, 894-904. [CrossRef] [PubMed]

5. Luang-In, V.; Narbad, A.; Nueno-Palop, C.; Mithen, R.; Bennett, M.; Rossiter, J.T. The metabolism of methylsulfinylalkyl- and methylthioalkyl-glucosinolates by a selection of human gut bacteria. Mol. Nutr. Food Res. 2014, 58, 875-883. [CrossRef] [PubMed]

6. Saladino, F.; Bordin, K.; Luciano, F.B.; Franzón, M.F.; Mañes, J.; Meca, G. Glucosinolates. Glucosinolates 2016. [CrossRef]

7. Miao, H.; Wang, J.; Cai, C.; Chang, J.; Zhao, Y.; Wang, Q. Accumulation of Glucosinolates in Broccoli. In Glucosinolates; Mérillon, J.M., Ramawat, K.G., Eds.; Springer International Publishing: New York, NY, USA, 2017; pp. 431-461. [CrossRef]

8. Ahuja, I.; Van Dam, N.M.; Winge, P.; Trælnes, M.; Heydarova, A.; Rohloff, J.; Langaas, M.; Bones, A.M. Plant defence responses in oilseed rape MINELESS plants after attack by the cabbage moth Mamestra brassicae. J. Exp. Bot. 2015, 66, 579-592. [CrossRef]

9. Falk, K.L.; Kästner, J.; Bodenhausen, N.; Schramm, K.; Europe PMC Funders Group. The role of glucosinolates and the jasmonic acid pathway in resistance of Arabidopsis thaliana against molluskan herbivores. Mol. Ecol. 2016, 23, 1188-1203. [CrossRef]

10. Borges, A.; Abreu, A.C.; Ferreira, C.; Saavedra, M.J.; Simões, L.C.; Simões, M. Antibacterial activity and mode of action of selected glucosinolate hydrolysis products against bacterial pathogens. J. Food Sci. Technol. 2015, 52, 4737-4748. [CrossRef]

11. Abdull Razis, A.F.; Noor, N.M. Sulforaphane is Superior to Glucoraphanin in Modulating Carcinogen-Metabolising Enzymes in Hep G2 Cells. Asian Pacific J. Cancer Prev. 2013, 14, 4235-4238. [CrossRef]

12. Abdull Razis, A.F.; Bagatta, M.; De Nicola, G.R.; Iori, R.; Ioannides, C. Intact glucosinolates modulate hepatic cytochrome $\mathrm{P} 450$ and phase II conjugation activities and may contribute directly to the chemopreventive activity of cruciferous vegetables. Toxicology 2010, 277, 74-85. [CrossRef] [PubMed]

13. Das, N.; Berhow, M.A.; Angelino, D.; Jeffery, E.H. Camelina sativa defatted seed meal contains both alkyl sulfinyl glucosinolates and quercetin that synergize bioactivity. J. Agric. Food Chem. 2014, 62, 8385-8391. [CrossRef]

14. Vale, A.P.; Santos, J.; Brito, N.V.; Fernandes, D.; Rosa, E.; Beatriz, M.; Oliveira, P.P. Evaluating the impact of sprouting conditions on the glucosinolate content of Brassica oleracea sprouts. Phytochemistry 2015, 115, 252-260. [CrossRef] [PubMed]

15. Carmen, S.; Tan, M.G.; Noel, M. Glucosinolates, Degradation Products and Myrosinase Activity in Raphanus sativus Linn. Pharmacogn. J. 2019. [CrossRef]

16. Fechner, J.; Kaufmann, M.; Herz, C.; Eisenschmidt, D.; Lamy, E.; Kroh, L.W.; Hanschen, F.S. The major glucosinolate hydrolysis product in rocket (Eruca sativa L.), sativin, is 1,3-thiazepane-2-thione: Elucidation of structure, bioactivity, and stability compared to other rocket isothiocyanates. Food Chem. 2018. [CrossRef] [PubMed]

17. Bhandari, S.R.; Kwak, J.H. Chemical composition and antioxidant activity in different tissues of brassica vegetables. Molecules 2015, 20, 1228-1243. [CrossRef]

18. Ku, K.M.; Jeffery, E.H.; Juvik, J.A.; Kushad, M.M. Correlation of Quinone Reductase Activity and Allyl Isothiocyanate Formation among Different Genotypes and Grades of Horseradish Roots. J. Agric. Food Chem. 2015, 63, 2947-2955. [CrossRef] 
19. Lee, M.K.; Chun, J.H.; Byeon, D.H.; Chung, S.O.; Park, S.U.; Park, S.; Arasu, M.V.; Al-Dhabi, N.A.; Lim, Y.P.; Kim, S.J. Variation of glucosinolates in 62 varieties of Chinese cabbage (Brassica rapa L. ssp. pekinensis) and their antioxidant activity. LWT Food Sci. Technol. 2014, 58, 93-101. [CrossRef]

20. Hahn, C.; Müller, A.; Kuhnert, N.; Albach, D. Diversity of Kale (Brassica oleracea var. sabellica): Glucosinolate Content and Phylogenetic Relationships. J. Agric. Food Chem. 2016. [CrossRef]

21. Huseby, S.; Koprivova, A.; Lee, B.R.; Saha, S.; Mithen, R.; Wold, A.B.; Bengtsson, G.B.; Kopriva, S. Diurnal and light regulation of sulphur assimilation and glucosinolate biosynthesis in Arabidopsis. J. Exp. Bot. 2013, 64, 1039-1048. [CrossRef]

22. Kurepina, N.; Kreiswirth, B.N.; Mustaev, A. Growth-inhibitory activity of natural and synthetic isothiocyanates against representative human microbial pathogens. J. Appl. Microbiol. 2013, 115, 943-954. [CrossRef] [PubMed]

23. Anderson, R.H.; Lensing, C.J.; Forred, B.J.; Amolins, M.W.; Aegerter, C.L.; Vitiello, P.F.; Mays, J.R. Differentiating Antiproliferative and Chemopreventive Modes of Activity for Electron-Deficient Aryl Isothiocyanates against Human MCF-7 Cells. ChemMedChem 2018, 13, 1695-1710. [CrossRef] [PubMed]

24. Wu, H.; Feng, J.; Lin, K.; Zhang, X. Synthesis and Herbicidal Activity of Substituted Pyrazole Isothiocyanates. Molecules 2012, 17, 12187-12196. [CrossRef] [PubMed]

25. Tang, J.; Niu, J.; Wang, W.; Huo, H.; Li, J.; Luo, L.; Cao, Y. p-Aromatic Isothiocyanates: Synthesis and Anti Plant Pathogen Activity. Russ. J. Gen. Chem. 2018, 88, 1252-1257. [CrossRef]

26. De Santi, M.; Galluzzi, L.; Lucarini, S.; Paoletti, M.F.; Fraternale, A.; Duranti, A.; De Marco, C.; Fanelli, M.; Zaffaroni, N.; Brandi, G.; et al. The indole-3-carbinol cyclic tetrameric derivative CTet inhibits cell proliferation via overexpression of p21/CDKN1A in both estrogen receptor-positive and triple-negative breast cancer cell lines. Breast Cancer Res. 2011, 13, R33. [CrossRef]

27. Vo, Q.V.; Trenerry, C.; Rochfort, S.; Wadeson, J.; Leyton, C.; Hughes, A.B. Synthesis and anti-inflammatory activity of aromatic glucosinolates. Bioorganic Med. Chem. 2013, 21, 5945-5954. [CrossRef]

28. Vo, Q.V.; Trenerry, C.; Rochfort, S.; Wadeson, J.; Leyton, C.; Hughes, A.B. Bioorganic \& Medicinal Chemistry Synthesis and anti-inflammatory activity of indole glucosinolates. Bioorg. Med. Chem. 2014, 22, 856-864. [CrossRef]

29. Vo, Q.V.; Rochfort, S.; Nam, P.C.; Nguyen, T.L.; Nguyen, T.T.; Mechler, A. Synthesis of aromatic and indole alpha-glucosinolates. Carbohydr. Res. 2018, 455, 45-53. [CrossRef]

30. Psurski, M.; Błaewska, K.; Gajda, A.; Gajda, T.; Wietrzyk, J.; Oleksyszyn, J. Synthesis and antiproliferative activity of novel $\alpha$ - And $\beta$-dialkoxyphosphoryl isothiocyanates. Bioorganic Med. Chem. Lett. 2011, 21, 4572-4576. [CrossRef]

31. Seo, M.S.; Jin, M.; Sohn, S.H.; Kim, J.S. Expression profiles of BrMYB transcription factors related to glucosinolate biosynthesis and stress response in eight subspecies of Brassica rapa. FEBS Open Bio 2017, 7, 1646-1659. [CrossRef]

32. Community, ECommission Regulation (EEC) No 1470 / 68 on the drawing and reduction of Whereas the measures provided for in this Regulation are in accordance with the opinion of the Management Having regard to Council Regula. Off. J. Eur. Commun. 1990, 33, 27-34.

33. Guo, L.; Yang, R.; Zhou, Y.; Gu, Z. Heat and hypoxia stresses enhance the accumulation of aliphatic glucosinolates and sulforaphane in broccoli sprouts. Eur. Food Res. Technol. 2016, 242, 107-116. [CrossRef]

34. Tian, M.; Xu, X.; Liu, Y.; Xie, L.; Pan, S. Effect of Se treatment on glucosinolate metabolism and health-promoting compounds in the broccoli sprouts of three cultivars. Food Chem. 2016, 190, 374-380. [CrossRef] [PubMed]

35. Arora, R.; Kumar, R.; Mahajan, J.; Vig, A.P.; Singh, B.; Singh, B.; Arora, S. 3-Butenyl isothiocyanate: A hydrolytic product of glucosinolate as a potential cytotoxic agent against human cancer cell lines. J. Food Sci. Technol. 2016, 53, 3437-3445. [CrossRef] [PubMed]

36. Al-Gendy, A.A.; Nematallah, K.A.; Zaghloul, S.S.; Ayoub, N.A. Glucosinolates profile, volatile constituents, antimicrobial, and cytotoxic activities of Lobularia libyca. Pharm. Biol. 2016, 54, 3257-3263. [CrossRef]

37. Li, Z.Y.; Wang, Y.; Shen, W.T.; Zhou, P. Content determination of benzyl glucosinolate and anti-cancer activity of its hydrolysis product in Carica papaya L. Asian Pac. J. Trop. Med. 2012, 5, 231-233. [CrossRef]

38. Bhattacharya, A.; Li, Y.; Wade, K.L.; Paonessa, J.D.; Fahey, J.W.; Zhang, Y. Allyl isothiocyanate-rich mustard seed powder inhibits bladder cancer growth and muscle invasion. Carcinogenesis 2010, 31, 2105-2110. [CrossRef] 
39. Boscaro, V.; Boffa, L.; Binello, A.; Amisano, G.; Fornasero, S.; Cravotto, G.; Gallicchio, M. Antiproliferative, proapoptotic, antioxidant and antimicrobial effects of Sinapis nigra L. And Sinapis alba L. Extracts. Molecules 2018, 23, 3004. [CrossRef]

40. Rajan, T.S.; De Nicola, G.R.; Iori, R.; Rollin, P.; Bramanti, P.; Mazzon, E. Anticancer activity of glucomoringin isothiocyanate in human malignant astrocytoma cells. Fitoterapia 2016, 110, 1-7. [CrossRef]

41. Antonini, E.; Iori, R.; Ninfali, P.; Scarpa, E.S. A Combination of Moringin and Avenanthramide 2f Inhibits the Proliferation of Hep3B Liver Cancer Cells Inducing Intrinsic and Extrinsic Apoptosis. Nutr. Cancer 2018, 70, 1159-1165. [CrossRef]

42. Michl, C.; Vivarelli, F.; Weigl, J.; De Nicola, G.R.; Canistro, D.; Paolini, M.; Iori, R.; Rascle, A. The chemopreventive phytochemical moringin isolated from Moringa oleifera seeds inhibits JAK/STAT signaling. PLoS ONE 2016, 11, 1-20. [CrossRef] [PubMed]

43. Müller, C.; Van Loon, J.; Ruschioni, S.; De Nicola, G.R.; Olsen, C.E.; Iori, R.; Agerbirk, N. Taste detection of the non-volatile isothiocyanate moringin results in deterrence to glucosinolate-adapted insect larvae. Phytochemistry 2015, 118, 139-148. [CrossRef] [PubMed]

44. Galuppo, M.; De Nicola, G.R.; Iori, R.; Dell'Utri, P.; Bramanti, P.; Mazzon, E. Antibacterial activity of glucomoringin bioactivated with myrosinase against two important pathogens affecting the health of long-term patients in hospitals. Molecules 2013, 18, 14340-14348. [CrossRef] [PubMed]

45. Giacoppo, S.; Rajan, T.S.; De Nicola, G.R.; Iori, R.; Rollin, P.; Bramanti, P.; Mazzon, E. The isothiocyanate isolated from moringa oleifera shows potent anti-inflammatory activity in the treatment of murine subacute Parkinson's disease. Rejuvenation Res. 2017, 20, 50-63. [CrossRef] [PubMed]

46. Blažević, I.; Đulović, A.; Čulić, V.Č.; Popović, M.; Guillot, X.; Burčul, F.; Rollin, P. Microwave-assisted versus conventional isolation of glucosinolate degradation products from Lunaria annua L. and their cytotoxic activity. Biomolecules 2020, 10, 215. [CrossRef]

47. Meyer, S.L.F.; Zasada, I.A.; Orisajo, S.B.; Morra, M.J. Mustard seed meal mixtures: Management of Meloidogyne incognita on pepper and potential phytotoxicity. J. Nematol. 2011, 43, 7-15.

48. Carpenter, E.L.; Le, M.N.; Miranda, C.L.; Reed, R.L.; Stevens, J.F.; Indra, A.K.; Ganguli-Indra, G. Photoprotective properties of isothiocyanate and nitrile glucosinolate derivatives from meadowfoam (Limnanthes alba) against UVB irradiation in human skin equivalent. Front. Pharmacol. 2018, 9, 1-10. [CrossRef]

49. Zasada, I.A.; Weiland, J.E.; Reed, R.L.; Stevens, J.F. Activity of meadowfoam (Limnanthes alba) seed meal glucolimnanthin degradation products against soilborne pathogens. J. Agric. Food Chem. 2012, 60, 339-345. [CrossRef]

50. Intanon, S.; Reed, R.L.; Stevens, J.F.; Hulting, A.G.; Mallory-Smith, C.A. Identification and phytotoxicity of a new glucosinolate breakdown product from meadowfoam (Limnanthes alba) seed meal. J. Agric. Food Chem. 2014, 62, 7423-7429. [CrossRef]

51. Mastelić, J.; Blaẑević, I.; Kosalec, I. Chemical composition and antimicrobial activity of volatiles from degenia velebitica, a european stenoendemic plant of the brassicaceae family. Chem. Biodivers. 2010, 7, 2755-2765. [CrossRef]

52. Radonić, A.; Blažević, I.; Mastelić, J.; Zekić, M.; Skočibušić, M.; Maravić, A. Phytochemical analysis and antimicrobial activity of Cardaria draba (L.) desv. volatiles. Chem. Biodivers. 2011, 8, 1170-1181. [CrossRef] [PubMed]

53. Blažević, I.; Radonić, A.; Skočibušić, M.; Denicola, G.R.; Montaut, S.; Iori, R.; Rollin, P.; Mastelić, J.; Zekić, M.; Maravić, A. Glucosinolate profiling and antimicrobial screening of aurinia leucadea (Brassicaceae). Chem. Biodivers. 2011, 8, 2310-2321. [CrossRef]

54. Blažević, I.; Đulović, A.; Maravić, A.; Čikeš Čulić, V.; Montaut, S.; Rollin, P. Antimicrobial and Cytotoxic Activities of Lepidium latifolium L. Hydrodistillate, Extract and Its Major Sulfur Volatile Allyl Isothiocyanate. Chem. Biodivers. 2019, 16. [CrossRef] [PubMed]

55. Lord, J.S.; Lazzeri, L.; Atkinson, H.J.; Urwin, P.E. Biofumigation for control of pale potato cyst nematodes: Activity of brassica leaf extracts and green manures on globodera pallida in vitro and in soil. J. Agric. Food Chem. 2011, 59, 7882-7890. [CrossRef]

56. Hashem, F.A.; Motawea, H.; El-Shabrawy, A.E.; Shaker, K.; El-Sherbini, S. Myrosinase hydrolysates of Brassica oleraceae L. Var. italica reduce the risk of colon cancer. Phyther. Res. 2012, 26, 743-747. [CrossRef] 
57. Liu, A.G.; Juvik, J.A.; Jeffery, E.H.; Berman-Booty, L.D.; Clinton, S.K.; Erdman, J.W. Enhancement of broccoli indole glucosinolates by methyl jasmonate treatment and effects on prostate carcinogenesis. J. Med. Food 2014, 17, 1177-1182. [CrossRef] [PubMed]

58. Subedi, L.; Venkatesan, R.; Kim, S.Y. Neuroprotective and anti-inflammatory activities of allyl isothiocyanate through attenuation of JNK/NF-kB/TNF- $\alpha$ signaling. Int. J. Mol. Sci. 2017, 18, 1423. [CrossRef]

59. Dekić, M.S.; Radulović, N.S.; Stojanović, N.M.; Randjelović, P.J.; Stojanović-Radić, Z.Z.; Najman, S.; Stojanović, S. Spasmolytic, antimicrobial and cytotoxic activities of 5-phenylpentyl isothiocyanate, a new glucosinolate autolysis product from horseradish (Armoracia rusticana P. Gaertn., B. Mey. \& Scherb., Brassicaceae). Food Chem. 2017, 232, 329-339. [CrossRef]

60. Popović, M.; Maravić, A.; Čulić, V.Č.; Đulović, A.; Burčul, F.; Blažević, I. Biological effects of glucosinolate degradation products from horseradish: A horse that wins the race. Biomolecules 2020, 10, 343. [CrossRef]

61. Kulisic-Bilusic, T.; Schmöller, I.; Schnäbele, K.; Siracusa, L.; Ruberto, G. The anticarcinogenic potential of essential oil and aqueous infusion from caper (Capparis spinosa L.). Food Chem. 2012, 132, 261-267. [CrossRef]

62. Lozano-Baena, M.D.; Tasset, I.; Obregón-Cano, S.; De Haro-Bailon, A.; Muñoz-Serrano, A.; Alonso-Moraga, Á. Antigenotoxicity and tumor growing inhibition by leafy Brassica carinata and sinigrin. Molecules 2015, 20, 15748-15765. [CrossRef] [PubMed]

63. Katsarou, D.; Omirou, M.; Liadaki, K.; Tsikou, D.; Delis, C.; Garagounis, C.; Krokida, A.; Zambounis, A.; Papadopoulou, K.K. Glucosinolate biosynthesis in Eruca sativa. Plant Physiol. Biochem. 2016, 109, $452-466$. [CrossRef] [PubMed]

64. Samson, M.; Porter, N.; Orekoya, O.; Hebert, J.R.; Adams, S.A.; Bennett, C.L.; Steck, S.E. Direct and Indirect Antioxidant Activity of Polyphenol- and Isothiocyanate-Enriched Fractions from Moringa oleifera Tugba. J. Agric. Food Chem. 2017, 155, 3-12. [CrossRef]

65. Aissani, N.; Tedeschi, P.; Maietti, A.; Brandolini, V.; Garau, V.L.; Caboni, P. Nematicidal activity of allylisothiocyanate from horseradish (Armoracia rusticana) roots against Meloidogyne incognita. J. Agric. Food Chem. 2013, 61, 4723-4727. [CrossRef] [PubMed]

66. Jeong, J.; Park, H.; Hyun, H.; Kim, J.; Kim, H.; Oh, H.I.; Hwang, H.S.; Kim, D.K.; Kim, H.H. Effects of glucosinolates from Turnip (Brassica rapa L.) root on bone formation by human osteoblast-like MG-63 cells and in normal young rats. Phyther. Res. 2015, 29, 902-909. [CrossRef]

67. Blažević, I.; Đulović, A.; Čikeš Čulić, V.; Burčul, F.; Ljubenkov, I.; Ruščić, M.; Generalić Mekinić, I. Bunias erucago L.: Glucosinolate profile and in vitro biological potential. Molecules 2019, 24, 741. [CrossRef]

68. Kestwal, R.M.; Lin, J.C.; Bagal-Kestwal, D.; Chiang, B.H. Glucosinolates fortification of cruciferous sprouts by sulphur supplementation during cultivation to enhance anti-cancer activity. Food Chem. 2011, 126, 1164-1171. [CrossRef]

69. Ibrahim, M.D.; Kntayya, S.B.; Mohd Ain, N.; Iori, R.; Ioannides, C.; Razis, A.F.A. Induction of apoptosis and cytotoxicity by raphasatin in human breast adenocarcinoma MCF-7 cells. Molecules 2018, 23, 3092. [CrossRef]

70. Miao, H.Y.; Wang, M.Y.; Chang, J.Q.; Tao, H.; Sun, B.; Wang, Q.M. Effects of glucose and gibberellic acid on glucosinolate content and antioxidant properties of Chinese kale sprouts. J. Zhejiang Univ. Sci. B 2017, 18, 1093-1100. [CrossRef]

71. Scholl, C.; Eshelman, B.D.; Barnes, D.M.; Hanlon, P.R. Raphasatin Is a More Potent Inducer of the Detoxification Enzymes Than Its Degradation Products. J. Food Sci. 2011, 76, C504-C511. [CrossRef]

72. Sotelo, T.; Lema, M.; Soengas, P.; Cartea, M.E.; Velasco, P. In Vitro Activity of Glucosinolates and Their Degradation Products against Brassica-Pathogenic Bacteria and Fungi. Appl. Environ. Microbiol. 2015, 81, 432-440. [CrossRef] [PubMed]

73. Bangarwa, S.K.; Norsworthy, J.K. Herbicidal activity of three isothiocyanates against yellow nutsedge and their dissipation under two plastic mulches. Crop Prot. 2015, 74, 145-149. [CrossRef]

74. Kaur, T.; Bhat, R.; Khajuria, M.; Vyas, R.; Kumari, A.; Nadda, G.; Vishwakarma, R.; Vyas, D. Dynamics of glucosinolate-myrosinase system during Plutella xylostella interaction to a novel host Lepidium latifolium $\mathrm{L}$. Plant Sci. 2016, 250, 1-9. [CrossRef] [PubMed]

75. Agnihotri, A.R.; Hulagabali, C.V.; Adhav, A.S.; Joshi, R.S. Mechanistic insight in potential dual role of sinigrin against Helicoverpa armigera. Phytochemistry 2018, 145, 121-127. [CrossRef] [PubMed]

76. Witzel, K.; Hanschen, F.S.; Schreiner, M.; Krumbein, A.; Ruppel, S.; Grosch, R. Verticillium Suppression Is Associated with the Glucosinolate Composition of Arabidopsis thaliana Leaves. PLoS ONE 2013, 8, e71877. [CrossRef] [PubMed] 
77. Kurt, Ş.; Güneş, U.; Soylu, E.M. In vitro and in vivo antifungal activity of synthetic pure isothiocyanates against Sclerotinia sclerotiorum. Pest Manag. Sci. 2011, 67, 869-875. [CrossRef]

78. Rivera-Vega, L.J.; Krosse, S.; de Graaf, R.M.; Garvi, J.; Garvi-Bode, R.D.; van Dam, N.M. Allelopathic effects of glucosinolate breakdown products in Hanza [Boscia senegalensis (Pers.) Lam.] processing waste water. Front. Plant Sci. 2015. [CrossRef]

79. Hinds, L.; Kenny, O.; Hossain, M.B.; Walsh, D.; Sheehy, E.; Evans, P.; Gaffney, M.; Rai, D.K. Evaluating the Antibacterial Properties of Polyacetylene and Glucosinolate Compounds with Further Identification of Their Presence within Various Carrot (Daucus carota) and Broccoli (Brassica oleracea) Cultivars Using High-Performance Liquid Chromatograph. J. Agric. Food Chem. 2017, 65, 7186-7191. [CrossRef]

80. Choi, K.D.; Kim, H.Y.; Shin, I.S. Antifungal activity of isothiocyanates extracted from horseradish (Armoracia rusticana) root against pathogenic dermal fungi. Food Sci. Biotechnol. 2017, 26, 847-852. [CrossRef]

81. Park, H.W.; Choi, K.D.; Shin, I.S. Antimicrobial activity of isothiocyanates(itcs) extracted from horseradish (Armoracia rusticana) root against oral microorganisms. Biocontrol Sci. 2013, 18, 163-168. [CrossRef]

82. Dias, C.; Aires, A.; Saavedra, M.J. Antimicrobial Activity of Isothiocyanates from Cruciferous Plants against Methicillin-Resistant Staphylococcus aureus (MRSA). IJMS 2014, 15, 19552-19561. [CrossRef]

83. Conrad, A.; Biehler, D.; Nobis, T.; Richter, H.; Engels, I.; Biehler, K.; Frank, U. Broad spectrum antibacterial activity of a mixture of isothiocyanates from nasturtium (Tropaeoli majoris herba) and horseradish (Armoraciae rusticanae radix). Drug Res. (Stuttg). 2013, 63, 65-68. [CrossRef] [PubMed]

84. Saavedra, M.; Borges, A.; Dias, C.; Aires, A.; Bennett, R.; Rosa, E.; Simões, M. Antimicrobial Activity of Phenolics and Glucosinolate Hydrolysis Products and their Synergy with Streptomycin against Pathogenic Bacteria. Med. Chem. (Los. Angeles). 2012, 6, 174-183. [CrossRef] [PubMed]

85. Kaiser, S.J.; Mutters, N.T.; Blessing, B.; Günther, F. Natural isothiocyanates express antimicrobial activity against developing and mature biofilms of Pseudomonas aeruginosa. Fitoterapia 2017, 119, 57-63. [CrossRef] [PubMed]

86. Herzallah, S.; Lledó, M.L.; Holley, R. Influence of $\mathrm{NaCl}$ and $\mathrm{NaNO} 3$ on sinigrin hydrolysis by foodborne bacteria. J. Food Prot. 2011, 74, 2162-2168. [CrossRef]

87. Hifnawy, M.S.; Salam, R.M.A.; Rabeh, M.A.; Aboseada, M.A. Glucosinolates, Glycosidically Bound Volatiles and Antimicrobial Activity of Brassica oleraceae Var. Botrytis, (Soultany Cultivar). Arch. biochem. Biophys. 2013, 3, 66-82.

88. Dufour, V.; Alazzam, B.; Ermel, G.; Thepaut, M.; Rossero, A.; Tresse, O.; Baysse, C. Antimicrobial activities of isothiocyanates against Campylobacter jejuni isolates. Front. Cell. Infect. Microbiol. 2012, 2, 53. [CrossRef]

89. Aires, A.; Dias, C.; Rosa, E.; Saavedra, M. Antimicrobial Susceptibility of Aeromonas Spp. Isolated from Pig Ileum Segments to Natural Isothiocyanates. Med. Chem. (Los. Angeles). 2013, 9, 861-866. [CrossRef]

90. Blažević, I.; Radonić, A.; Mastelić, J.; Zekić, M.; Skočibušić, M.; Maravić, A. Glucosinolates, glycosidically bound volatiles and antimicrobial activity of Aurinia sinuata (Brassicaceae). Food Chem. 2010, 121, 1020-1028. [CrossRef]

91. Malabed, R.S.; Noel, M.G.; Aton III, B.C.; Toribio, E.A.F. Characterization of the Glucosinolates and Isothiocyanates in Mustard (Brassica juncea L.) Extracts and Determination of Its Myrosinase Activity and Antioxidant Capacity. In Proceedings of the DLSU Research Congress 2014, Manila, Phillipines, 6-8 March 2014; pp. 1-7.

92. Biegańska-Marecik, R.; Radziejewska-Kubzdela, E.; Marecik, R. Characterization of phenolics, glucosinolates and antioxidant activity of beverages based on apple juice with addition of frozen and freeze-dried curly kale leaves (Brassica oleracea L. var. acephala L.). Food Chem. 2017, 230, 271-280. [CrossRef]

93. Lee, H.W.; Lee, C.G.; Rhee, D.K.; Um, S.H.; Pyo, S. Sinigrin inhibits production of inflammatory mediators by suppressing NF-kB/MAPK pathways or NLRP3 inflammasome activation in macrophages. Int. Immunopharmacol. 2017, 45, 163-173. [CrossRef] [PubMed]

94. Shirai, Y.; Fujita, Y.; Hashimoto, R.; Ohi, K.; Yamamori, H.; Yasuda, Y.; Ishima, T.; Suganuma, H.; Ushida, Y.; Takeda, M.; et al. Dietary intake of sulforaphane-rich broccoli sprout extracts during juvenile and adolescence can prevent phencyclidine-induced cognitive deficits at adulthood. PLoS ONE 2015, 10, e0127244. [CrossRef] [PubMed] 
95. Shiina, A.; Kanahara, N.; Sasaki, T.; Oda, Y.; Hashimoto, T.; Hasegawa, T.; Yoshida, T.; Iyo, M.; Hashimoto, K. An open study of sulforaphane-rich broccoli sprout extract in patients with schizophrenia. Clin. Psychopharmacol. Neurosci. 2015, 13, 62-67. [CrossRef] [PubMed]

96. Giacoppo, S.; Galuppo, M.; Iori, R.; De Nicola, G.R.; Bramanti, P.; Mazzon, E. The protective effects of bioactive (RS)-glucoraphanin on the permeability of the mice blood-brain barrier following experimental autoimmune encephalomyelitis. Eur. Rev. Med. Pharmacol. Sci. 2014, 18, 194-204.

97. Galuppo, M.; Giacoppo, S.; De Nicola, G.R.; Iori, R.; Mazzon, E.; Bramanti, P. RS-Glucoraphanin bioactivated with myrosinase treatment counteracts proinflammatory cascade and apoptosis associated to spinal cord injury in an experimental mouse model. J. Neurol. Sci. 2013, 334, 88-96. [CrossRef]

98. Blazevic, I.; Burcul, F.; Ruscic, M.; Mastelic, J. Glucosinolates, volatile constituents, and acetylcholinesterase inhibitory activity of Alyssoides utriculata. Chem. Nat. Compd. 2013, 49, 374-378. [CrossRef]

99. Kadir, N.H.A.; David, R.; Rossiter, J.T.; Gooderham, N.J. The selective cytotoxicity of the alkenyl glucosinolate hydrolysis products and their presence in Brassica vegetables. Toxicology 2015, 334, 59-71. [CrossRef]

100. Bassan, P.; Bhushan, S.; Kaur, T.; Arora, R.; Arora, S.; Vig, A.P. Extraction, profiling and bioactivity analysis of volatile glucosinolates present in oil extract of Brassica juncea var. raya. Physiol. Mol. Biol. Plants 2018, 24, 399-409. [CrossRef]

101. Srivastava, M.M.; Bansal, P.; Medhe, S.; Ganesh, N. In vitro anticancer activity of dietary bioagent (isothiocyanates) on HepG2 and B16F10 cell lines: A comparative study. Ann. Plant Sci. 2013, 234-237.

102. Radošević, K.; Srček, V.G.; Bubalo, M.C.; Rimac Brnčić, S.; Takács, K.; Redovniković, I.R. Assessment of glucosinolates, antioxidative and antiproliferative activity of broccoli and collard extracts. J. Food Compos. Anal. 2017, 61, 59-66. [CrossRef]

103. Abdull Razis, A.F.; Iori, R.; Ioannides, C. The natural chemopreventive phytochemical R-sulforaphane is a far more potent inducer of the carcinogen-detoxifying enzyme systems in rat liver and lung than the S-isomer. Int. J. Cancer 2011, 128, 2775-2782. [CrossRef] [PubMed]

104. Abdull Razis, A.F.; De Nicola, G.R.; Pagnotta, E.; Iori, R.; Ioannides, C. A glucosinolate-rich extract of Japanese Daikon perturbs carcinogen-metabolizing enzyme systems in rat, being a potent inducer of hepatic glutathione S-transferase. Eur. J. Nutr. 2013, 52, 1279-1285. [CrossRef] [PubMed]

105. Jakubikova, J.; Cervi, D.; Ooi, M.; Kim, K.; Nahar, S.; Klippel, S.; Cholujova, D.; Leiba, M.; Daley, J.F.; Delmore, J.; et al. Anti-tumor activity and signaling events triggered by the isothiocyanates, sulforaphane and phenethyl isothiocyanate, in multiple myeloma. Haematologica 2011, 96, 1170-1179. [CrossRef] [PubMed]

106. Qian, H.; Sun, B.; Miao, H.; Cai, C.; Xu, C.; Wang, Q. Variation of glucosinolates and quinone reductase activity among different varieties of Chinese kale and improvement of glucoraphanin by metabolic engineering. Food Chem. 2015, 168, 321-326. [CrossRef]

107. Ku, K.M.; Kim, M.J.; Jeffery, E.H.; Kang, Y.H.; Juvik, J.A. Profiles of Glucosinolates, Their Hydrolysis Products, and Quinone Reductase Inducing Activity from 39 Arugula (Eruca sativa Mill.) Accessions. J. Agric. Food Chem. 2016, 64, 6524-6532. [CrossRef]

108. Jeong, Y.J.; Cho, H.J.; Chung, F.L.; Wang, X.; Hoe, H.S.; Park, K.K.; Kim, C.H.; Chang, H.W.; Lee, S.R.; Chang, Y.C. Isothiocyanates suppress the invasion and metastasis of tumors by targeting FAK/MMP-9 activity. Oncotarget 2017, 8, 63949-63962. [CrossRef]

109. Veprik, A.; Khanin, M.; Linnewiel-Hermoni, K.; Danilenko, M.; Levy, J.; Sharoni, Y. Polyphenols, isothiocyanates, and carotenoid derivatives enhance estrogenic activity in bone cells but inhibit it in breast cancer cells. Am. J. Physiol. Endocrinol. Metab. 2012, 303, 815-824. [CrossRef]

110. Hać, A.; Brokowska, J.; Rintz, E.; Bartkowski, M.; Węgrzyn, G.; Herman-Antosiewicz, A. Mechanism of selective anticancer activity of isothiocyanates relies on differences in DNA damage repair between cancer and healthy cells. Eur. J. Nutr. 2019, 59, 421-1432. [CrossRef]

111. Vauzour, D.; Buonfiglio, M.; Corona, G.; Chirafisi, J.; Vafeiadou, K.; Angeloni, C.; Hrelia, S.; Hrelia, P.; Spencer, J.P.E. Sulforaphane protects cortical neurons against 5-S-cysteinyl-dopamine-induced toxicity through the activation of ERK1/2, NrF-2 and the upregulation of detoxification enzymes. Mol. Nutr. Food Res. 2010, 54, 532-542. [CrossRef]

112. Rajendran, P.; Delage, B.; Dashwood, W.M.; Yu, T.W.; Wuth, B.; Williams, D.E.; Ho, E.; Dashwood, R.H. Histone deacetylase turnover and recovery in sulforaphane-treated colon cancer cells: Competing actions of 14-3-3 and Pin1 in HDAC3/SMRT corepressor complex dissociation/reassembly. Mol. Cancer 2011, 10, 68. [CrossRef] 
113. Tafakh, M.S.; Saidijam, M.; Ranjbarnejad, T.; Malih, S.; Mirzamohammadi, S.; Najafi, R. Sulforaphane, a Chemopreventive Compound, Inhibits Cyclooxygenase-2 and Microsomal Prostaglandin e Synthase-1 Expression in Human HT-29 Colon Cancer Cells. Cells Tissues Organs 2019, 206, 46-53. [CrossRef] [PubMed]

114. Curran, K.M.; Bracha, S.; Wong, C.P.; Beaver, L.M.; Stevens, J.F.; Ho, E. Sulforaphane absorption and histone deacetylase activity following single dosing of broccoli sprout supplement in normal dogs. Vet. Med. Sci. 2018, 4, 357-363. [CrossRef] [PubMed]

115. Kntayya, S.B.; Ibrahim, M.D.; Ain, N.M.; Iori, R.; Ioannides, C.; Abdull Razis, A.F. Induction of apoptosis and cytotoxicity by isothiocyanate sulforaphene in human hepatocarcinoma HepG2 cells. Nutrients 2018, 10, 718. [CrossRef] [PubMed]

116. Abdull Razis, A.F.; De Nicola, G.R.; Pagnotta, E.; Iori, R.; Ioannides, C. 4-Methylsulfanyl-3-butenyl isothiocyanate derived from glucoraphasatin is a potent inducer of rat hepatic phase II enzymes and a potential chemopreventive agent. Arch. Toxicol. 2012, 86, 183-194. [CrossRef]

117. Förster, N.; Mewis, I.; Glatt, H.; Haack, M.; Brigelius-Flohé, R.; Schreiner, M.; Ulrichs, C. Characteristic single glucosinolates from: Moringa oleifera: Induction of detoxifying enzymes and lack of genotoxic activity in various model systems. Food Funct. 2016, 7, 4660-4674. [CrossRef]

118. Kim, J.; Bang, H.; Ahn, M.; Choi, Y.; Kim, G.O.; Shin, T. Allyl isothiocyanate reduces liver fibrosis by regulating Kupffer cell activation in rats. J. Vet. Med. Sci. 2018, 80, 893-897. [CrossRef]

119. Awasthi, S.; Saraswathi, N.T. Sinigrin, a major glucosinolate from cruciferous vegetables restrains non-enzymatic glycation of albumin. Int. J. Biol. Macromol. 2016, 83, 410-415. [CrossRef]

120. Baenas, N.; Piegholdt, S.; Schloesser, A.; Moreno, D.A.; García-Viguera, C.; Rimbach, G.; Wagner, A.E. Metabolic activity of radish sprouts derived isothiocyanates in drosophila melanogaster. Int. J. Mol. Sci. 2016, 17, 251. [CrossRef]

121. Hanlon, N.; Konsue, N.; Coldham, N.; Sauer, M.J.; Ioannides, C. Exposure to isothiocyanates suppresses urinary mutagenicity in rats treated with heterocyclic amine IQ: Lack of association with CYP1 activity. Nutr. Cancer 2011, 63, 300-305. [CrossRef]

122. Galletti, S.; Bagatta, M.; Branca, F.; Argento, S.; De Nicola, G.R.; Cianchetta, S.; Iori, R.; Ninfali, P. Isatis canescens is a rich source of glucobrassicin and other health-promoting compounds. J. Sci. Food Agric. 2015, 95, 158-164. [CrossRef]

123. Krajka-Kuźniak, V.; Szaefer, H.; Bartoszek, A.; Baer-Dubowska, W. Modulation of rat hepatic and kidney phase II enzymes by cabbage juices: Comparison with the effects of indole-3-carbinol and phenethyl isothiocyanate. Br. J. Nutr. 2011, 105, 816-826. [CrossRef] [PubMed]

124. Hajra, S.; Patra, A.R.; Basu, A.; Bhattacharya, S. Prevention of doxorubicin (DOX)-induced genotoxicity and cardiotoxicity: Effect of plant derived small molecule indole-3-carbinol (I3C) on oxidative stress and inflammation. Biomed. Pharmacother. 2018, 101, 228-243. [CrossRef] [PubMed]

125. Hajra, S.; Basu, A.; Singha Roy, S.; Patra, A.R.; Bhattacharya, S. Attenuation of doxorubicin-induced cardiotoxicity and genotoxicity by an indole-based natural compound $3,3^{\prime}$-diindolylmethane (DIM) through activation of Nrf2/ARE signaling pathways and inhibiting apoptosis. Free Radic. Res. 2017, 51, 812-827. [CrossRef] [PubMed]

126. Müller, C.; Schulz, M.; Pagnotta, E.; Ugolini, L.; Yang, T.; Matthes, A.; Lazzeri, L.; Agerbirk, N. The Role of the Glucosinolate-Myrosinase System in Mediating Greater Resistance of Barbarea verna than B. vulgaris to Mamestra brassicae Larvae. J. Chem. Ecol. 2018, 44, 1190-1205. [CrossRef] [PubMed]

127. Abreu, A.; Borges, A.; Simoes, L.; Saavedra, M.; Simoes, M. Antibacterial Activity of Phenyl Isothiocyanate on Escherichia coli and Staphylococcus aureus. Med. Chem. (Los. Angeles) 2013, 9, 756-761. [CrossRef]

128. Martín, J.C.; Higuera, B.L. Glucosinolate composition of Colombian accessions of mashua (Tropaeolum tuberosum Ruíz \& Pavón), structural elucidation of the predominant glucosinolate and assessment of its antifungal activity. J. Sci. Food Agric. 2016, 96, 4702-4712. [CrossRef]

129. Burčul, F.; Generalić Mekinić, I.; Radan, M.; Rollin, P.; Blažević, I. Isothiocyanates: Cholinesterase inhibiting, antioxidant, and anti-inflammatory activity. J. Enzyme Inhib. Med. Chem. 2018, 33, 577-582. [CrossRef]

130. Lee, Y.M.; Cho, H.J.; Ponnuraj, S.P.; Kim, J.; Kim, J.; Kim, G.S.; Park, J.H. Phenethyl isothiocyanate inhibits 12-0-tetradecanoylphorbol-13-acetate-induced inflammatory responses in mouse skin. J. Med. Food 2011, 14, 377-385. [CrossRef] 
131. Rajan, T.S.; Giacoppo, S.; Iori, R.; De Nicola, G.R.; Grassi, G.; Pollastro, F.; Bramanti, P.; Mazzon, E. Anti-inflammatory and antioxidant effects of a combination of cannabidiol and moringin in LPS-stimulated macrophages. Fitoterapia 2016, 112, 104-115. [CrossRef]

132. Fahey, J.W.; Wade, K.L.; Stephenson, K.K.; Shi, Y.; Liu, H.; Panjwani, A.A.; Warrick, C.R.; Olson, M.E. A strategy to deliver precise oral doses of the glucosinolates or isothiocyanates from moringa oleifera leaves for use in clinical studies. Nutrients 2019, 11, 1547. [CrossRef]

133. Malabed, R.S.; Noel, M.G. Characterization of the glucosinolates and isothiocyanates in Malunggay (Moringa oleifera L.) Extracts and determinationof their myrosinae activity and anticancer properties. In Proceedings of the DLSU Research Congress 2013, Manila, Phillipines, 7-9 March 2013; pp. 1-6.

134. Yu, C.; Gong, A.Y.; Chen, D.; Solelo Leon, D.; Young, C.Y.; Chen, X.M. Phenethyl isothiocyanate inhibits androgen receptor-regulated transcriptional activity in prostate cancer cells through suppressing PCAF. Mol. Nutr. Food Res. 2013, 57, 1825-1833. [CrossRef] [PubMed]

135. Mi, L.; Gan, N.; Chung, F.L. Isothiocyanates inhibit proteasome activity and proliferation of multiple myeloma cells. Carcinogenesis 2011, 32, 216-223. [CrossRef] [PubMed]

136. Larkin, R.P.; Honeycutt, C.W.; Olanya, O.M. Management of Verticillium Wilt of Potato with Disease-Suppressive Green Manures and as Affected by Previous Cropping History. Plant Dis. 2011, 95, 568-576. [CrossRef] [PubMed]

137. Schlaeppi, K.; Abou-Mansour, E.; Buchala, A.; Mauch, F. Disease resistance of Arabidopsis to Phytophthora brassicae is established by the sequential action of indole glucosinolates and camalexin. Plant J. 2010, 62, 840-851. [CrossRef] [PubMed]

138. Liochev, S.I. Reactive oxygen species and the free radical theory of aging. Free Radic. Biol. Med. 2013, 60, 1-4. [CrossRef] [PubMed]

139. Oh, S.K.; Tsukamoto, C.; Kim, K.W.; Choi, M.R. Investigation of glucosinolates, and the antioxidant activity of Dolsan leaf mustard kimchi extract using HPLC and LC-PDA-MS/MS. J. Food Biochem. 2017, 41. [CrossRef]

140. Chester, K.; Zahiruddin, S.; Ahmad, A.; Khan, W.; Paliwal, S.; Ahmad, S. Bioautography-based Identification of Antioxidant Metabolites of Solanum nigrum L. and Exploration. Pharmacogn. Mag. 2017, 15, 104. [CrossRef]

141. Nguyen Phan, T.X. A Density Functional Theory Study of Antioxidant Activity of Isothiocyanates in Broccoli Sprouts (Brassica Oleracea L.). Vietnam J. Sci. Technol. 2018, 54, 306. [CrossRef]

142. Eichholzer, M.; Steinbrecher, A.; Kaaks, R.; Teucher, B.; Linseisen, J.; Rohrmann, S. Effects of selenium status, dietary glucosinolate intake and serum glutathione S-transferase $\alpha$ activity on the risk of benign prostatic hyperplasia. BJU Int. 2012, 110, 879-885. [CrossRef]

143. Psurski, M.; Wietrzyk, J.; Oleksyszyn, J. 1035 Studies over the Natural Isothiocyanates Structure-activity and Structure-mechanism of Action Relationship. Eur. J. Cancer 2012, 48, S249. [CrossRef]

144. Skugor, S.; Jodaa Holm, H.; Bjelland, A.K.; Pino, J.; Evensen, Ø.; Krasnov, A.; Wadsworth, S. Nutrigenomic effects of glucosinolates on liver, muscle and distal kidney in parasite-free and salmon louse infected Atlantic salmon. Parasites Vectors 2016, 9, 639. [CrossRef] [PubMed]

145. Tahata, S.; Singh, S.V.; Lin, Y.; Hahm, E.R.; Beumer, J.H.; Christner, S.M.; Rao, U.N.; Sander, C.; Tarhini, A.A.; Tawbi, H.; et al. Evaluation of biodistribution of sulforaphane after administration of oral broccoli sprout extract in melanoma patients with multiple atypical nevi. Cancer Prev. Res. 2018, 11, 429-438. [CrossRef] [PubMed]

146. Bahadoran, Z.; Tohidi, M.; Nazeri, P.; Mehran, M.; Azizi, F.; Mirmiran, P. Effect of broccoli sprouts on insulin resistance in type 2 diabetic patients: A randomized double-blind clinical trial. Int. J. Food Sci. Nutr. 2012, 63, 767-771. [CrossRef] [PubMed]

147. Traka, M.H.; Melchini, A.; Coode-Bate, J.; Kadhi, O.A.; Saha, S.; Defernez, M.; Troncoso-Rey, P.; Kibblewhite,H.; O'Neill, C.M.; Bernuzzi, F.; et al. Transcriptional changes in prostate of men on active surveillance after a 12-mo glucoraphanin-rich broccoli intervention-results from the Effect of Sulforaphane on prostate CAncer PrEvention (ESCAPE) randomized controlled trial. Am. J. Clin. Nutr. 2019, 109, 1133-1144. [CrossRef]

148. Alumkal, J.J.; Slottke, R.; Schwartzman, J.; Cherala, G.; Munar, M.; Graff, J.N.; Beer, T.M.; Ryan, C.W.; Koop, D.R.; Gibbs, A.; et al. A phase II study of sulforaphane-rich broccoli sprout extracts in men with recurrent prostate cancer. Invest. New Drugs 2015, 33, 480-490. [CrossRef]

149. Brown, R.H.; Reynolds, C.; Brooker, A.; Talalay, P.; Fahey, J.W. Sulforaphane improves the bronchoprotective response in asthmatics through Nrf2-mediated gene pathways. Respir. Res. 2015, 16, 106. [CrossRef] 
150. Wise, R.A.; Holbrook, J.T.; Criner, G.; Sethi, S.; Rayapudi, S.; Sudini, K.R.; Sugar, E.A.; Burke, A.; Thimmulappa, R.; Singh, A.; et al. Lack of effect of oral sulforaphane administration on Nrf2 expression in COPD: A randomized, double-blind, placebo controlled trial. PLoS ONE 2016, 11, e0163716. [CrossRef]

151. Atwell, L.L.; Zhang, Z.; Mori, M.; Farris, P.E.; Vetto, J.T.; Naik, A.M.; Oh, K.Y.; Thuillier, P.; Ho, E.; Shannon, J. Sulforaphane bioavailability and chemopreventive activity in women scheduled for breast biopsy. Cancer Prev. Res. 2015, 8, 1184-1191. [CrossRef]

152. Ma, L.; Liu, G.; Sampson, L.; Willett, W.C.; Hu, F.B.; Sun, Q. Dietary glucosinolates and risk of type 2 diabetes in 3 prospective cohort studies. Am. J. Clin. Nutr. 2018, 107, 617-625. [CrossRef]

153. Ma, L.; Liu, G.; Zong, G.; Sampson, L.; Hu, F.B.; Willett, W.C.; Rimm, E.B.; Manson, J.E.; Rexrode, K.M.; Sun, Q. Intake of glucosinolates and risk of coronary heart disease in three large prospective cohorts of US men and women. Clin. Epidemiol. 2018, 10, 749-762. [CrossRef]

154. Banerjee, A.; Variyar, P.S.; Chatterjee, S.; Sharma, A. Effect of post harvest radiation processing and storage on the volatile oil composition and glucosinolate profile of cabbage. Food Chem. 2014, 151, 22-30. [CrossRef] [PubMed]

155. Nath, A.; Bagchi, B.; Misra, L.K.; Deka, B.C. Changes in post-harvest phytochemical qualities of broccoli florets during ambient and refrigerated storage. Food Chem. 2011, 127, 1510-1514. [CrossRef]

156. Villarreal-García, D.; Nair, V.; Cisneros-Zevallos, L.; Jacobo-Velázquez, D.A. Plants as biofactories: Postharvest stress-induced accumulation of phenolic compounds and glucosinolates in broccoli subjected to wounding stress and exogenous phytohormones. Front. Plant Sci. 2016, 7, 45. [CrossRef] [PubMed]

157. Hwang, E.S. Effect of cooking method on antioxidant compound contents in cauliflower. Prev. Nutr. Food Sci. 2019, 24, 210-216. [CrossRef]

158. Sut, S.; Boschiero, I.; Solana, M.; Malagoli, M.; Bertucco, A.; Dall'Acqua, S. Supercritical CO2 extraction of eruca sativa using cosolvents: Phytochemical composition by LC-MS analysis. Molecules 2018, 23, 3240. [CrossRef]

159. Rafińska, K.; Pomastowski, P.; Rudnicka, J.; Krakowska, A.; Maruśka, A.; Narkute, M.; Buszewski, B. Effect of solvent and extraction technique on composition and biological activity of Lepidium sativum extracts. Food Chem. 2019, 289, 16-25. [CrossRef]

160. Luciano, F.B.; Belland, J.; Holley, R.A. Microbial and chemical origins of the bactericidal activity of thermally treated yellow mustard powder toward Escherichia coli O157:H7 during dry sausage ripening. Int. J. Food Microbiol. 2011, 145, 69-76. [CrossRef]

161. Yuan, G.; Wang, X.; Guo, R.; Wang, Q. Effect of salt stress on phenolic compounds, glucosinolates, myrosinase and antioxidant activity in radish sprouts. Food Chem. 2010, 121, 1014-1019. [CrossRef]

162. Guo, R.F.; Yuan, G.F.; Wang, Q.M. Effect of $\mathrm{NaCl}$ treatments on glucosinolate metabolism in broccoli sprouts. J. Zhejiang Univ. Sci. B 2013, 14, 124-131. [CrossRef]

163. Del Carmen Rodríguez-Hernández, M.; Moreno, D.A.; Carvajal, M.; Del Carmen Martínez-Ballesta, M. Genotype influences sulfur metabolism in broccoli (Brassica oleracea L.) under elevated $\mathrm{CO} 2$ and $\mathrm{NaCl}$ stress. Plant Cell Physiol. 2014, 55, 2047-2059. [CrossRef]

164. Ku, K.M.; Jeffery, E.H.; Juvik, J.A. Exogenous methyl jasmonate treatment increases glucosinolate biosynthesis and quinone reductase activity in kale leaf tissue. PLoS ONE 2014, 9, e103407. [CrossRef] [PubMed]

165. Guo, L.; Yang, R.; Gu, Z. Cloning of genes related to aliphatic glucosinolate metabolism and the mechanism of sulforaphane accumulation in broccoli sprouts under jasmonic acid treatment. J. Sci. Food Agric. 2016, 96, 4329-4336. [CrossRef] [PubMed]

166. Chiu, Y.C.; Juvik, J.A.; Ku, K.M. Targeted metabolomic and transcriptomic analyses of "red russian" kale (Brassicae napus var. pabularia) following methyl jasmonate treatment and larval infestation by the cabbage looper (Trichoplusia ni hübner). Int. J. Mol. Sci. 2018, 19, 1058. [CrossRef] [PubMed]

167. Ku, K.M.; Jeffery, E.H.; Juvik, J.A. Optimization of methyl jasmonate application to broccoli florets to enhance health-promoting phytochemical content. J. Sci. Food Agric. 2014, 94, 2090-2096. [CrossRef]

168. Ku, K.M.; Jeffery, E.H.; Juvik, J.A. Influence of seasonal variation and methyl jasmonate mediated induction of glucosinolate biosynthesis on quinone reductase activity in broccoli florets. J. Agric. Food Chem. 2013, 61, 9623-9631. [CrossRef]

169. Ku, K.M.; Choi, J.H.; Kushad, M.M.; Jeffery, E.H.; Juvik, J.A. Pre-harvest Methyl Jasmonate Treatment Enhances Cauliflower Chemoprotective Attributes Without a Loss in Postharvest Quality. Plant Foods Hum. Nutr. 2013, 68, 113-117. [CrossRef] 
170. Wiesner, M.; Schreiner, M.; Glatt, H. High mutagenic activity of juice from pak choi (Brassica rapa ssp. chinensis) sprouts due to its content of 1-methoxy-3-indolylmethyl glucosinolate, and its enhancement by elicitation with methyl jasmonate. Food Chem. Toxicol. 2014, 67, 10-16. [CrossRef]

171. Kim, M.J.; Chiu, Y.C.; Kim, N.K.; Park, H.M.; Lee, C.H.; Juvik, J.A.; Ku, K.M. Cultivar-specific changes in primary and secondary metabolites in pak choi (Brassica rapa, Chinensis group) by methyl jasmonate. Int. J. Mol. Sci. 2017, 18, 1004. [CrossRef]

172. Zhang, K.; Su, H.; Zhou, J.; Liang, W.; Liu, D.; Li, J. Overexpressing the Myrosinase Gene TGG1 Enhances Stomatal Defense Against Pseudomonas syringae and Delays Flowering in Arabidopsis. Front. Plant Sci. 2019, 10, 1-14. [CrossRef]

173. Schiavon, M.; Berto, C.; Malagoli, M.; Trentin, A.; Sambo, P.; Dall'Acqua, S.; Pilon-Smits, E.A.H. Selenium biofortification in radish enhances nutritional quality via accumulation of methyl-selenocysteine and promotion of transcripts and metabolites related to glucosinolates, phenolics amino acids. Front. Plant Sci. 2016. [CrossRef]

174. Marino, D.; Ariz, I.; Lasa, B.; Santamaría, E.; Fernández-Irigoyen, J.; González-Murua, C.; Aparicio Tejo, P.M. Quantitative proteomics reveals the importance of nitrogen source to control glucosinolate metabolism in Arabidopsis thaliana and Brassica oleracea. J. Exp. Bot. 2016, 67, 3313-3323. [CrossRef] [PubMed]

175. Xu, F.; Yang, Z.; Chen, X.; Jin, P.; Wang, X.; Zheng, Y. 6-Benzylaminopurine Delays Senescence and Enhances Health-Promoting Compounds of Harvested Broccoli. J. Agric. Food Chem. 2012, 60, 234-240. [CrossRef] [PubMed]

176. Xu, F.; Chen, X.; Yang, Z.; Jin, P.; Wang, K.; Shang, H.; Wang, X.; Zheng, Y. Maintaining quality and bioactive compounds of broccoli by combined treatment with 1-methylcyclopropene and 6-benzylaminopurine. J. Sci. Food Agric. 2013, 93, 1156-1161. [CrossRef] [PubMed]

177. Jin, P.; Yao, D.; Xu, F.; Wang, H.; Zheng, Y. Effect of light on quality and bioactive compounds in postharvest broccoli florets. Food Chem. 2015, 172, 705-709. [CrossRef] [PubMed]

178. Sontowski, R.; Gorringe, N.J.; Pencs, S.; Schedl, A.; Touw, A.J.; van Dam, N.M. Same Difference? Low and High Glucosinolate Brassica rapa Varieties Show Similar Responses Upon Feeding by Two Specialist Root Herbivores. Front. Plant Sci. 2019, 10, 1451. [CrossRef]

179. Touw, A.J.; Verdecia Mogena, A.; Maedicke, A.; Sontowski, R.; van Dam, N.M.; Tsunoda, T. Both Biosynthesis and Transport Are Involved in Glucosinolate Accumulation During Root-Herbivory in Brassica rapa. Front. Plant Sci. 2020, 10, 1653. [CrossRef]

180. Rozpadek, P.; Ślesak, I.; Cebula, S.; Waligórski, P.; Dziurka, M.; Skoczowski, A.; Miszalski, Z. Ozone fumigation results in accelerated growth and persistent changes in the antioxidant system of Brassica oleracea L. var. capitata f. alba. J. Plant Physiol. 2013, 170, 1259-1266. [CrossRef]

181. Stotz, H.U.; Sawada, Y.; Shimada, Y.; Hirai, M.Y.; Sasaki, E.; Krischke, M.; Brown, P.D.; Saito, K.; Kamiya, Y. Role of camalexin, indole glucosinolates, and side chain modification of glucosinolate-derived isothiocyanates in defense of Arabidopsis against Sclerotinia sclerotiorum. Plant J. 2011, 67, 81-93. [CrossRef]

182. Kato, M.; Imayoshi, Y.; Iwabuchi, H.; Shimomura, K. Kinetic changes in glucosinolate-derived volatiles by heat-treatment and myrosinase activity in nakajimana (Brassica rapa L. cv. nakajimana). J. Agric. Food Chem. 2011, 59, 11034-11039. [CrossRef]

183. Atwell, L.L.; Hsu, A.; Wong, C.P.; Stevens, J.F.; Bella, D.; Yu, W.; Pereira, C.B.; Löhr, C.V.; Christensen, J.M.; Roderick, H. Multiple rare alleles at LDLR and APOA5 confer risk for early- onset myocardial infarction. Nature 2015, 518, 102-106. [CrossRef]

184. Okunade, O.; Niranjan, K.; Ghawi, S.K.; Kuhnle, G.; Methven, L. Supplementation of the Diet by Exogenous Myrosinase via Mustard Seeds to Increase the Bioavailability of Sulforaphane in Healthy Human Subjects after the Consumption of Cooked Broccoli. Mol. Nutr. Food Res. 2018, 62, 1-6. [CrossRef]

185. Ghawi, S.K.; Methven, L.; Niranjan, K. The potential to intensify sulforaphane formation in cooked broccoli (Brassica oleracea var. italica) using mustard seeds (Sinapis alba). Food Chem. 2013, 138, 1734-1741. [CrossRef] [PubMed]

186. Cordeiro, R.P.; Wu, C.; Holley, R.A. Contribution of endogenous plant myrosinase to the antimicrobial activity of deodorized mustard against Escherichia coli O157:H7 in fermented dry sausage. Int. J. Food Microbiol. 2014, 189, 132-138. [CrossRef] [PubMed] 
187. Wu, Y.; Shen, Y.; Zhu, Y.; Mupunga, J.; Zou, L.; Liu, C.; Liu, S.; Mao, J. Broccoli ingestion increases the glucosinolate hydrolysis activity of microbiota in the mouse gut. Int. J. Food Sci. Nutr. 2019, 70, 585-594. [CrossRef] [PubMed]

188. Totušek, J.; Tříska, J.; Lefnerová, D.; Strohalm, J.; Vrchotová, N.; Zendulka, O.; Průchová, J.; Chaloupková, J.; Novotná, P.; Houška, M. Contents of sulforaphane and total isothiocyanates, antimutagenic activity, and inhibition of clastogenicity in pulp juices from Cruciferous plants. Czech J. Food Sci. 2011, 29, 548-556. [CrossRef]

189. Okunade, O.A.; Ghawi, S.K.; Methven, L.; Niranjan, K. Thermal and pressure stability of myrosinase enzymes from black mustard (Brassica nigra L. W.D.J. Koch. var. nigra), brown mustard (Brassica juncea L. Czern. var. juncea) and yellow mustard (Sinapsis alba L. subsp. maire) seeds. Food Chem. 2015, 187, 485-490. [CrossRef] [PubMed]

190. Campos, D.; Aguilar-Galvez, A.; García-Ríos, D.; Chirinos, R.; Limaymanta, E.; Pedreschi, R. Postharvest storage and cooking techniques affect the stability of glucosinolates and myrosinase activity of Andean mashua tubers (Tropaeolum tuberosum). Int. J. Food Sci. Technol. 2019, 54, 2387-2395. [CrossRef]

191. Lee, J.G.; Lim, S.; Kim, J.; Lee, E.J. The mechanism of deterioration of the glucosinolate-myrosynase system in radish roots during cold storage after harvest. Food Chem. 2017, 233, 60-68. [CrossRef]

192. Hanschen, F.S.; Kühn, C.; Nickel, M.; Rohn, S.; Dekker, M. Leaching and degradation kinetics of glucosinolates during boiling of Brassica oleracea vegetables and the formation of their breakdown products. Food Chem. 2018, 263, 240-250. [CrossRef]

193. Radziejewska-Kubzdela, E.; Olejnik, A.; Biegańska-Marecik, R. Effect of pretreatment on bioactive compounds in wild rocket juice. J. Food Sci. Technol. 2019, 56, 5234-5242. [CrossRef]

194. Niu, Y.; Rogiewicz, A.; Wan, C.; Guo, M.; Huang, F.; Slominski, B.A. Effect of microwave treatment on the efficacy of expeller pressing of Brassica napus rapeseed and Brassica juncea mustard seeds. J. Agric. Food Chem. 2015, 63, 3078-3084. [CrossRef] [PubMed]

195. Verma, A.; Sharma, A.; Rai, P.K.; Kumar, D. Effect of microwave pre-treatment on quality parameters in Indian mustard. J. Food Sci. Technol. 2019, 56, 4956-4965. [CrossRef] [PubMed]

196. Rybarczyk-Plonska, A.; Hagen, S.F.; Borge, G.I.A.; Bengtsson, G.B.; Hansen, M.K.; Wold, A.B. Glucosinolates in broccoli (Brassica oleracea L. var. italica) as affected by postharvest temperature and radiation treatments. Postharvest Biol. Technol. 2016, 116, 16-25. [CrossRef] 